\title{
Cancer Stem Cell Functions in Hepatocellular Carcinoma and Comprehensive Therapeutic Strategies
}

\author{
Yu-Chin Liu ${ }^{1,2}$, Chau-Ting Yeh ${ }^{3}$ and Kwang-Huei Lin ${ }^{1,2,3,4, *(\mathbb{D})}$ \\ 1 Department of Biochemistry, College of Medicine, Chang-Gung University, Taoyuan 333, Taiwan; \\ k1506820@gmail.com \\ 2 Department of Biomedical Sciences, College of Medicine, Chang-Gung University, Taoyuan 333, Taiwan \\ 3 Liver Research Center, Chang Gung Memorial Hospital, Taoyuan 333, Taiwan; chauting@adm.cgmh.org.tw \\ 4 Research Center for Chinese Herbal Medicine, College of Human Ecology, Chang Gung University of \\ Science and Technology, Taoyuan 333, Taiwan \\ * Correspondence: khlin@mail.cgu.edu.tw; Tel./Fax: +886-3-211-8263
}

Received: 5 May 2020; Accepted: 22 May 2020; Published: 26 May 2020

\begin{abstract}
Hepatocellular carcinoma (HCC) is a significant cause of cancer-related mortality owing to resistance to traditional treatments and tumor recurrence after therapy, which leads to poor therapeutic outcomes. Cancer stem cells (CSC) are a small subset of tumor cells with the capability to influence self-renewal, differentiation, and tumorigenesis. A number of surface markers for liver cancer stem cell (LCSC) subpopulations (EpCAM, CD133, CD44, CD13, CD90, OV-6, CD47, and side populations) in HCC have been identified. LCSCs play critical roles in regulating HCC stemness, self-renewal, tumorigenicity, metastasis, recurrence, and therapeutic resistance via genetic mutations, epigenetic disruption, signaling pathway dysregulation, or alterations microenvironment. Accumulating studies have shown that biomarkers for LCSCs contribute to diagnosis and prognosis prediction of HCC, supporting their utility in clinical management and development of therapeutic strategies. Preclinical and clinical analyses of therapeutic approaches for HCC using small molecule inhibitors, oncolytic measles viruses, and anti-surface marker antibodies have demonstrated selective, efficient, and safe targeting of LCSC populations. The current review focuses on recent reports on the influence of LCSCs on HCC stemness, tumorigenesis, and multiple drug resistance (MDR), along with LCSC-targeted therapeutic strategies for HCC.
\end{abstract}

Keywords: hepatocellular carcinoma; liver cancer stem cells; stemness; self-renewal; tumorigenicity; therapeutic resistance

\section{Introduction}

Embryogenesis of both normal and tumor cells involves similar processes, including proliferation, motility, homing, dynamic morphologic changes, cellular heterogeneity, and interactions with the microenvironment. However, carcinogenesis is described as deregulation of malignant organogenesis regulated by abnormally proliferating and metastatic cancer and activated stromal cells that trigger angiogenesis, fibrosis, and inflammation [1]. One such case is liver cancer, which is classified as primary or secondary. Primary liver cancer refers to initiation of liver cell growth, and secondary liver cancer refers to spread of cancer cells to other organs from the liver. Primary liver cancer can be classified as growth of a single lump or growth in many places in the liver at the same time. Primary liver cancer types include hepatocellular carcinoma, cholangiocarcinoma, liver angiosarcoma, and hepatoblastoma. Hepatocellular carcinoma (HCC), also known as hepatoma, is the most common type worldwide, accounting for $~ 75 \%$ of all liver cancers. HCC is influenced by several important 
risk factors, with two distinct mechanisms of molecular pathogenesis: hepatitis infection (HBV or $\mathrm{HCV}$ ) or toxin/environmental (alcohol or aflatoxin B) or metabolic (insulin resistance, obesity, type II diabetes or dyslipidemia in nonalcoholic HCC) factors that trigger liver tissue damage, leading to cirrhosis associated with hepatic regeneration and subsequent HCC [2] and genetic/epigenetic changes that influence the expression patterns of oncogenes or tumor suppressor genes [3-7]. The above factors are correlated with multiple dysregulated signaling pathways, such as growth factor-mediated angiogenic signaling (vascular endothelial growth factor (VEGF), platelet-derived growth factor (PDGF), epidermal growth factor (EGF), insulin-like growth factor (IGF), hepatocyte growth factor (HGF)/c-MET), mitogen-activated protein kinase (MAPK), phosphatidylinositol-3 kinase (PI3K)/AKT/mammalian target of rapamycin (mTOR), and Wnt/ $\beta$-catenin pathways, which contribute to HCC development and tumorigenesis [8]. Elucidation of these signaling mechanisms is interesting from a therapeutic perspective, since targeting them may aid in reversing, delaying, or preventing the occurrence of HCC. Sorafenib is a first-line treatment approved by the United States Food and Drug Administration (USFDA) shown to benefit post-therapy survival rates in unresectable HCC cases. Subsequently identified target drugs, including regorafenib and lenvatinib, are currently used as second-line treatments for HCC. The above drugs can be effectively combined with radiation therapy and chemotherapy for clinical treatment of HCC. However, the therapeutic effects remain limited, which is ascribed to high recurrence and drug resistance of liver cancer stem cells (LCSCs), a subpopulation of liver cancer cells isolated via flow cytometry with self-renewal, differentiation, and tumorigenesis capabilities [9] hat play critical roles in tumor progression and therapeutic resistance. In this review, the functions of LCSCs in HCC and targeted therapeutic strategies are comprehensively discussed.

\section{Identification and Plasticity of LCSCs}

\subsection{Concept of Cancer Stem Cells (CSCs)}

Cancer stem cells (CSCs) have similar characteristics to normal stem cells, including self-renewal and differentiation. CSCs are also called as tumor-initiating cells (T-ICs) or cancer stem-like cells, which were first evidenced by injecting the AML cells into SCID mice by xenotransplant; the experiments indicated that expression of specific CSCs marker $\left(\mathrm{CD} 34^{+} \mathrm{CD} 38^{-}\right)$could promote production of large numbers of colony-forming progenitors [10]. This discovery suggested a new CSCs concept, according to which heterogeneity and tumor hierarchy is organized by a subset of cells with CSCs. This avoids traditional thoughts that heterogeneity is the progressive accumulation of multiple genetic [11] or epigenetic changes [12]. Several CSCs have been isolated from malignancies including lung cancer, pancreatic cancer, breast cancer, prostate cancer, colon cancer, glioma, and liver carcinoma [13-16]. CSCs have been found to possess highly tumorigenic, metastatic, and chemotherapy- and radiation-resistant properties, possibly leading to tumor relapse after therapy. CSCs evade multiple drug actions (MDR) with the aid of various intrinsic and external mechanisms [17]. Intrinsic mechanisms of chemoresistance include DNA damage repair pathway activation, high-level expression of drug efflux-related proteins, the capability of reconstituting original tumors, and the influence of epithelial-to-mesenchymal transition (EMT) and self-renewal-related genes [18]. External mechanisms of chemoresistance include activation of signaling pathways involved in epithelial-mesenchymal transition (EMT), hypoxia stimulation, and abnormal angiogenesis [17]. Besides, CSCs enter a dormant state (arrest in the G0 phase) of reduction of cell proliferation activity and persist resistance to chemotherapy for a few years, eventually leading to relapse. The relationship between tumor microenvironment (TME) and CSCs play an important role in influencing resistance therapeutics and promoting trans-differentiation of non-CSCs into CSCs by providing anti-apoptosis, stemness-maintaining factors, and matrix components. Thus, to study how to improve therapeutic resistance of CSCs in cancer is a critical issue. 


\subsection{Correlation between Hepatocellular Carcinoma and Cancer Stem Cells}

CSCs of hepatocellular carcinoma (HCC) are termed liver cancer stem cells (LCSCs). LCSCs display specific features, such as the ability to generate new tumors displaying the phenotypes of xenotransplanted tumors, chemoresistance, metastasis, and recurrence [19] (Figure 1 and Table 1). Both metastasis and recurrence are associated with drug resistance [20]. So far, several surface markers and side population cells (SP) of HCC have been isolated, including EpCAM, CD133, CD44, CD13, CD90, CD24, CD47, and OV6. Other surface markers, such as K19, c-kit, ABCG2, and ALDH, have additionally been identified, which individually affect resistance to radiotherapy or chemotherapy and tumorigenesis by influencing drug efflux-related gene expression [21-24], activation of growth signaling, and stem cell-related and anti-apoptosis pathways [25-27]. LCSCs possess the capability of circulation within the body that significantly promotes distant metastasis and homing ability, compared to other tumor cell types. In other words, LCSCs promote tumor growth of primary cancer cells and metastasis of transplanted secondary tumors, leading to recurrence of HCC [28]. LCSCs are therefore closely related to metastasis, recurrence, and MDR and serve as an important diagnostic marker for HCC. In recent years, accumulating research has focused on identifying different surface markers of HCC through fluorescence-activated and magnetically activated cell sorting approaches, which could be effectively developed for eliminating LCSCs to achieve inhibition of tumor recurrence [29].

Table 1. Surface markers influencing the signaling pathways, phenotypes, and resistance to clinical drugs in LCSCs.

\begin{tabular}{|c|c|c|c|c|}
\hline LCSCs & $\begin{array}{l}\text { Phenotypes of LCSCs } \\
\text { (Source) }\end{array}$ & $\begin{array}{l}\text { Signaling Involving } \\
\text { LCSCs }\end{array}$ & $\begin{array}{l}\text { Resistance to } \\
\text { Clinical Drug }\end{array}$ & Ref. \\
\hline EpCAM & $\begin{array}{l}\text { cell-cell adhesion, metabolism, } \\
\text { cell signaling, differentiation, } \\
\text { metastasis, regeneration, } \\
\text { organogenesis, tumorigenesis, } \\
\text { chemoresistance and } \\
\text { self-renewal (Hep3B, HepG2, } \\
\text { Huh7, Huh1, and } \\
\text { Dt81Hepa1-6 cells) } \\
\text { tumorigenic, cell cycle }\end{array}$ & $\begin{array}{l}\text { Activation of the Wnt } \\
\text { signaling pathway }\end{array}$ & Sorafenib & [30-33] \\
\hline CD133 & $\begin{array}{l}\text { progression, differentiation, } \\
\text { chemoresistance, and } \\
\text { self-renewal (Huh7, SMMC7721, } \\
\text { PLC8024,PLC8024, HepG2, and } \\
\text { HCCLM3 cells) }\end{array}$ & Activation of $\mathrm{AKT} / \mathrm{PKB}$, & $\begin{array}{l}\text { Doxorubicin, } \\
\text { Fluorouracil (5-FU) } \\
\text { and Sorafenib }\end{array}$ & {$[27,34-36]$} \\
\hline CD44 & $\begin{array}{c}\text { proliferation, survival, } \\
\text { migration/invasion, and } \\
\text { chemoresistance, and } \\
\text { self-renewal (primary HCC, } \\
\text { HepG2, Hep3B, Huh7, SUN-368, } \\
\text { SUN-354, SMMC-7721, and } \\
\text { MHCC97-H cells) }\end{array}$ & $\begin{array}{c}\text { Activation of } \\
\text { AKT/GSK-3 } \beta / \beta \text {-catenin, } \\
\text { and ERK/Snail pathways }\end{array}$ & Doxorubicin & {$[21,37-42]$} \\
\hline CD13 & $\begin{array}{c}\text { chemoresistance, tumorigenesis } \\
\text { and self-renewal (Huh7, PLC, } \\
\text { and HepG2 cells) }\end{array}$ & $\begin{array}{l}\text { Activation of ERK1/2 } \\
\text { signaling pathway }\end{array}$ & $\begin{array}{l}\text { Sorafenib, } \\
\text { Doxorubicin, and } \\
\text { Fluorouracil (5-FU) }\end{array}$ & {$[43,44]$} \\
\hline CD90 & $\begin{array}{c}\text { tumorigenesis, metastasis, } \\
\text { self-renewal and } \\
\text { chemoresistance (MHCC97L, } \\
\text { PLC, HepG2, Hep3B, primary } \\
\text { HCC, and JHH-6 cells) }\end{array}$ & $\begin{array}{l}\text { Activation of mTOR } \\
\text { signaling pathway }\end{array}$ & Doxorubicin & [45-48] \\
\hline $\mathrm{CD} 24$ & $\begin{array}{c}\text { metastasis, differentiation, } \\
\text { self-renewal and } \\
\text { chemoresistance (MHCC97H, } \\
\text { HCCLM3, PLC/PRF/5, Huh7, } \\
\text { and Hep3B cells) }\end{array}$ & $\begin{array}{c}\text { Autophagy activation, } \\
\text { activation of AKT/mTOR } \\
\text { signaling pathway, and } \\
\text { Notch1 signaling } \\
\text { pathway }\end{array}$ & Cisplatin, Sorafenib & [49-52] \\
\hline OV-6 & $\begin{array}{l}\text { self-renewal, tumorigenicity, } \\
\text { and chemoresistance } \\
\text { (SMMC7721, and HuH7 cells) }\end{array}$ & $\begin{array}{c}\text { Activation of } \\
\text { Wnt } / \beta \text {-catenin signaling }\end{array}$ & Cisplatin & {$[53,54]$} \\
\hline Side population & $\begin{array}{l}\text { differentiation, chemoresistance, } \\
\text { and metastasis (Huh7, } \\
\text { PLC/PRF/5, HCCLM3, } \\
\text { MHCC97-H, MHCC97-L, and } \\
\text { Hep3B cells) }\end{array}$ & $\begin{array}{l}\text { Activation of AKT } \\
\text { signaling pathway }\end{array}$ & $\begin{array}{l}\text { Doxorubicin, } \\
\text { Fluorouracil (5-FU), } \\
\text { and Gemcitabine }\end{array}$ & {$[23,24,55]$} \\
\hline
\end{tabular}


Table 1. Cont.

\begin{tabular}{|c|c|c|c|c|}
\hline LCSCs & $\begin{array}{c}\text { Phenotypes of LCSCs } \\
\text { (Source) }\end{array}$ & $\begin{array}{c}\text { Signaling Involving } \\
\text { LCSCs }\end{array}$ & $\begin{array}{l}\text { Resistance to } \\
\text { Clinical Drug }\end{array}$ & Ref. \\
\hline $\mathrm{CD} 47$ & $\begin{array}{l}\text { self-renewal, tumor initiating, } \\
\text { tumorigenicity, and } \\
\text { chemoresistance (MHCC97L, } \\
\text { PLC, and Huh7 cells) }\end{array}$ & $\begin{array}{c}\text { Activation of IL-6/STAT3 } \\
\text { signaling pathway, and } \\
\text { NF-kB }\end{array}$ & $\begin{array}{l}\text { Doxorubicin, } \\
\text { Sorafenib }\end{array}$ & [56-58] \\
\hline SALL4 & $\begin{array}{c}\text { proliferation, differentiation, } \\
\text { and chemoresistance (Huh7, } \\
\text { PLC/PRF/5, and patients } \\
\text { of HCC) }\end{array}$ & $\begin{array}{c}\text { Interaction with NuRD, } \\
\text { regulation of PTEN, and } \\
\text { PI3K/AKT } \\
\text { signaling pathway }\end{array}$ & Fluorouracil (5-FU) & {$[59,60]$} \\
\hline $\mathrm{CD}_{13}{ }^{+} \mathrm{CD} 133^{+}$ & $\begin{array}{c}\text { tumor initiation, } \\
\text { chemoresistance, and } \\
\text { anti-apoptosis (Huh7 and } \\
\text { PLC cells) }\end{array}$ & $\begin{array}{l}\text { Reduction of } \\
\text { ROS-induced DNA } \\
\text { damage and inhibition } \\
\text { of apoptosis }\end{array}$ & $\begin{array}{c}\text { Doxorubicin, } \\
\text { Fluorouracil (5-FU) }\end{array}$ & [43] \\
\hline $\mathrm{CD} 13^{+} \mathrm{CD} 90^{+}$ & $\begin{array}{c}\text { tumor initiation, } \\
\text { chemoresistance, and } \\
\text { anti-apoptosis (Huh7 and } \\
\text { PLC cells) }\end{array}$ & $\begin{array}{l}\text { Reduction of } \\
\text { ROS-induced DNA } \\
\text { damage and inhibition } \\
\text { of apoptosis }\end{array}$ & $\begin{array}{c}\text { Doxorubicin, } \\
\text { Fluorouracil (5-FU) }\end{array}$ & [43] \\
\hline $\mathrm{EpCAM}^{+} \mathrm{CD} 0^{+}$ & $\begin{array}{l}\text { metastasis, tumorigenesis } \\
\text { (patients of HCC and } \\
\text { primary HCC) }\end{array}$ & $\begin{array}{l}\text { activation of the } \\
\text { TGF- } \beta \text { pathway }\end{array}$ & & [61] \\
\hline $\begin{array}{l}\mathrm{CD} 90^{+} \mathrm{CXCR} 4^{+} \text {and } \\
\mathrm{CD} 133^{+} \mathrm{CD} 90^{+}\end{array}$ & $\begin{array}{l}\text { tumor development, tumor } \\
\text { spheres, and metastasis } \\
\text { (primary HCC) }\end{array}$ & & & [62] \\
\hline
\end{tabular}

\section{3. $E p C A M$}

The epithelial cell adhesion molecule, EpCAM, belonging to the type I transmembrane protein family is glycosylated and expressed in various tissues, including human epithelial and tumor tissues as well as progenitor/stem cells [63]. The EpCAM structure comprises an extracellular domain with epidermal growth factor (EGF) and thyroglobulin repeat-like domains, a single transmembrane domain, and a short 26-amino acid intracellular domain designated EpICD [63]. Interestingly, EpCAM is not only detectable in normal adult hepatocytes also expressed in embryonic liver, bile duct epithelium, and proliferating bile ductulus in cirrhotic liver and is thus considered a progenitor/stem cell marker in adult liver [64]. Data from systematic analyses suggest that EpCAM expression is essential for all human adenocarcinomas, including specific types of squamous cell carcinoma, retinoblastoma, and hepatocellular carcinoma $[65,66]$. EpCAM is not only involved in cell-cell adhesion, as the name indicates, but also cell proliferation, migration, cell cycle metabolism, signaling, differentiation, metastasis, regeneration, organogenesis, and tumorigenesis of the liver. EpCAM has additionally been detected on the surface of LCSCs and pancreatic CSCs [32,67]. Transplantation of isolated EpCAM ${ }^{+} \mathrm{CD}_{4} 5^{-}$cells from HCC patients into NOD/SCID mice initiated tumor formation, whereas $\mathrm{EpCAM}^{-} \mathrm{CD} 45^{-}$cells failed to form tumors, suggesting that $\mathrm{EpCAM}^{+}$confers the stem/progenitor cell trait of HCC and promotes tumor growth [68]. EpCAM is involved in two major signaling pathways, specifically, intramembrane proteolysis and shedding of the extracellular domain [69]. EpICD is found in the cytoplasm generated from EpCAM cleavage by two important proteins (tumor necrosis factor-alpha converting enzyme (ACE) and presenilin 2 (PS-2)) and subsequently interacts with $\beta$-catenin through four-and-a-half LIM domain protein 2 (FHL2) [63]. Simultaneously, accumulation of $\beta$-catenin in the cytoplasm is dependent on inhibition of phosphorylation through induction of the $\beta$-catenin degradation complex (AXIN, APC, GSK3) by the Wnt signaling pathway [31]. Accumulated $\beta$-catenin interacts with FHL2 and EpICD to form a large protein complex that is translocated to the nucleus. The nuclear protein complex regulates transcription of EpCAM target genes, including c-myc, cyclins, and TCF1 $[30,63]$. Gene expression and pathway analyses suggest that activation of Wnt $/ \beta$-catenin signaling enriches the EpCAM ${ }^{+}$cell population. EpCAM ${ }^{+}$-rich cell subpopulations isolated from HCC present liver cancer stem cell features, which promote self-renewal, differentiation, and invasiveness [70]. Dt81 Hepa1-6, a new cell line derived from Hepa1-6 through in vivo passage in C57BL/6 mice, displays higher tumorigenicity, which is attributable to increased EpCAM and $\beta$-catenin expression [71]. In another study, EpCAM-positive circulating tumor cells were identified from HCC 
patients undergoing curative resection, which displayed stem cell-like and EMT phenotypes that were likely to cause tumor recurrence after surgical resection [68]. Additionally, stemness genes, such as Nanog, Sox2, and Oct4, were expressed in EpCAM-positive HCC cells and TSC2-AKT signaling activated upon Sorafenib treatment, further exacerbating hepatocellular carcinoma progression [33]. In another study, gene and protein expression profiles were analyzed from 245 and 144 hepatocellular carcinoma patients, respectively. EpCAM ${ }^{+}$cells abundantly expressed $\mathrm{CDH} 4$, a chromatin remodeling enzyme, and influenced PPAR and DNA double-stranded break repairs to enhance chemoresistance of HCC cells [72]. Clinical analyses showed higher EpCAM expression in HCC tumor than adjacent normal liver tissue and positive correlation with differentiation grade among the clinicopathological parameters examined. Kaplan-Meier analyses showed that at advanced clinical stages, high EpCAM expression and poor differentiation grade were associated with poor survival rates. These results collectively support the utility of EpCAM in HCC as a predictive biomarker for unfavorable prognosis [73].

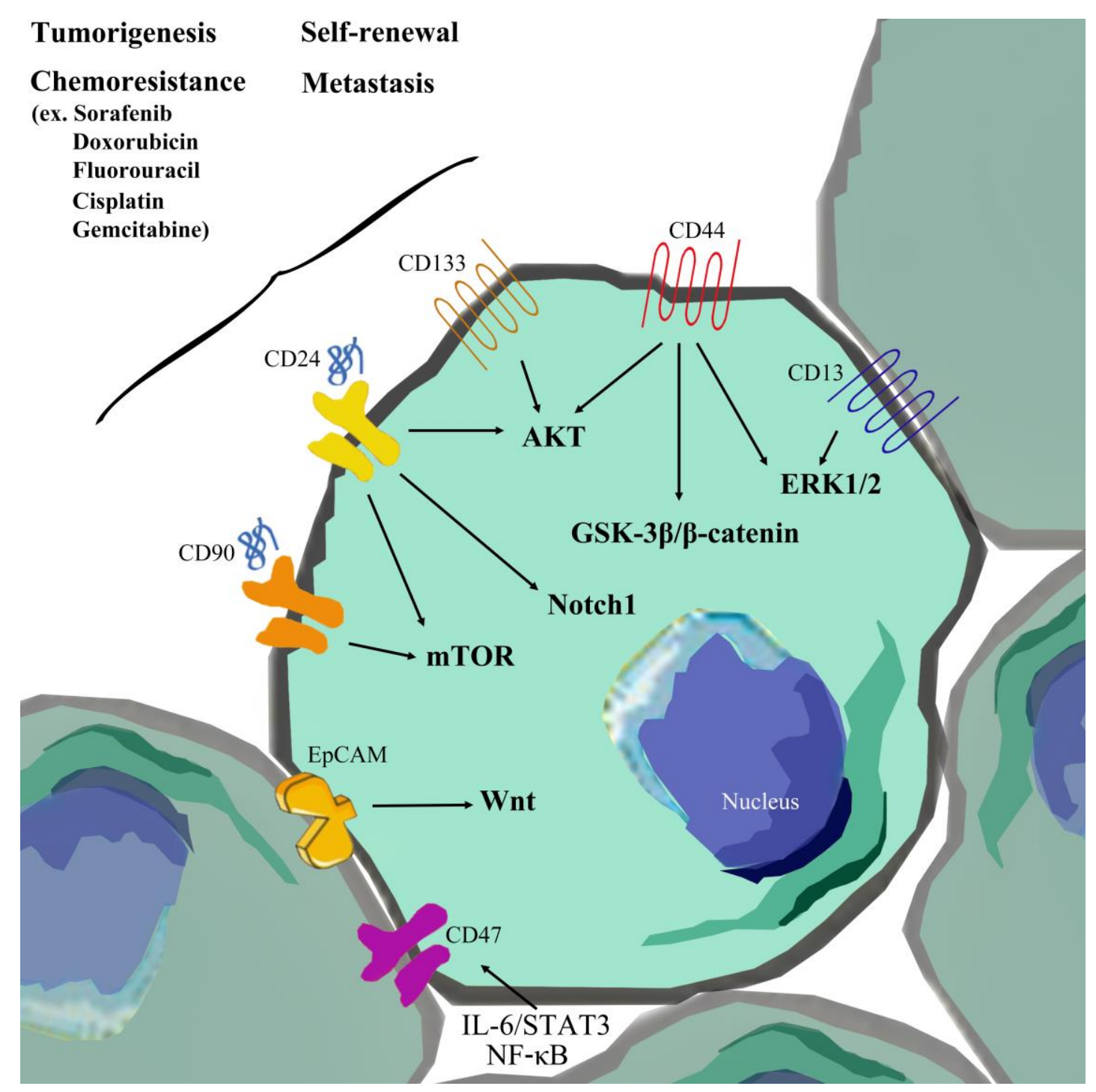

Figure 1. Activation of signaling pathways in liver cancer stem cells (LCSCs) influences hepatocellular carcinoma (HCC) development. Surface markers (including EpCAM, CD133, CD44, CD13, CD90, $\mathrm{CD} 24$, and CD47) influence the activation of signaling pathways, phenotypes, and resistance to clinical drugs in LCSCs 


\section{4. $C D 133$}

CD133 (human prominin-1, PROM1) is a glycoprotein with five transmembrane domains and two larger extracellular glycosylation chains that serves as an important surface marker, showing abundant expression in both cytoplasm and nucleus of various tumor tissues, including hepatocellular carcinoma (HCC), brain tumor, pancreatic cancer, prostate cancer, and colon cancer [74-78]. The CD133 ${ }^{+}$ subpopulation was initially isolated from Huh7, one of the benign HCC cell lines, and was shown to play potential roles in proliferation and tumorigenesis [34] in both SMMC7721 and PLC8024 cells [35,79]. Additionally, 0 65\% human HCC cells are CD133 ${ }^{+}$. Knockout of CD133 in HCC cells is reported to reduce tumorigenicity and cell cycle progression [35]. Similar findings were obtained with clinical HCC patients, whereby high CD133 expression was correlated with poor prognosis. Simultaneously, increased CD133 levels in HCC patients were associated with shorter overall survival and higher recurrence rates, indicating that CD133 may be a suitable prognostic marker [80]. Recent studies suggest that CD133 induces differentiation into non-hepatocyte-like lineages and may act as a progenitor cell marker not only in damaged liver and HCC tissue but also cholangiocarcinoma, both in vitro and in vivo [81,82]. CD133 is involved in numerous molecular mechanisms, including self-renewal, multi-lineage differentiation, and tumorigenic and therapeutic resistance. Following EMT promotion of HBx-infected hepatoma cells, TGF- $\beta$ expression of neighboring endothelial cells is increased, leading to significantly enhanced CD133 expression [36]. Aquaporin 3 (AQP3) is reported to maintain stemness and self-renewal capacity through inducing CD133 transcription activity via promoting stimulation and nuclear translocation of signal transducer and activator of transcription 3 (STAT3) and CD133 promoter-acetylated histone H3 [83]. In patients with hepatocellular carcinoma (HCC) recurrence, the majority of hepatic stem/progenitor cell (HSC/HPC) biomarkers are overexpressed, including cytokeratin 19, ABCG2, CD133, Nestin, and CD44, and angiogenesis agents CD34, VEGF, and PD-ECGF. Additionally, RFA-induced VEGF promotes tumor stemness and tumorigenesis via Nanog and activation of VEGFR2, which are positively correlated with CD133 expression in HCC tissues derived from patients with early recurrence. These results clearly suggest that VEGF and $\mathrm{CD} 133^{+}$stemness markers are positively correlated with early HCC recurrence [84]. Isolated $\mathrm{CD} 133^{+}$subpopulations of HCC cells and xenograft mouse models confer increased chemoresistance to doxorubicin (DOX) and fluorouracil (5-FU) through activation of Akt/PKB and Bcl-2 survival pathways [27]. Additionally, the epigenome cooperates with other regulatory factors, such as non-coding RNAs, allowing differentiation between short non-coding RNAs (miRNAs and sRNAs; $<200$ nucleotides) and long non-coding RNAs (lncRNAs; $>200$ nucleotides) [85]. MiR-130b overexpressed in $\mathrm{CD}_{13} 3^{+}$tumor-initiating cells (TIC) of HCC enhances chemoresistance, tumorigenicity, and self-renewal via suppression of its downstream target gene, TP53INP1 [86]. Dysregulation of lncRNAs in primary HCCs has additionally been shown to influence HCC tumorigenesis.

\section{5. $C D 44$}

CD44 is a transmembrane glycoprotein encoded by a single gene expressed as several isoforms that acts as a receptor for hyaluronic acid (HA). CD44 has been identified in both normal and tumor cells. Tumor cell behaviors, including proliferation, survival, migration/invasion, and chemoresistance, are closely associated with upregulation of CD44 [37-40]. Tumor-associated macrophages (TAM) are a class of immune cells often found in the microenvironment of solid tumors. TAMs produce IL-6 with subsequent activation of signal transducer and activator of transcription 3 (STAT3) and promote expansion of $\mathrm{CD} 44^{+}$populations and tumorigenesis in cultures as well as growth of xenograft tumors in mice [87]. CD44s, one of the isoforms of CD44, plays a completely opposite role to CD44. Knockout of the CD44 gene in HCC expressing CD44s only resulted in decreased maintenance of CSCs and increased drug sensitivity [88]. CD44 overexpression in HCC patients and cell lines is regulated by TGF- $\beta$ and confers a TGF- $\beta$-mediated mesenchymal phenotype through increased AKT/GSK-3 $\beta / \beta$-catenin activity [42], with a further major influence on EMT-related genes, such as positive correlation with vimentin expression, negative correlation with E-cadherin expression, 
high percentage of phospho-Smad2-positive nuclei, and reduced disease-free and overall survival [89]. Simultaneous analysis of clinicopathological parameters of other patient groups revealed that CD44 is also involved in local aggressive HCC recurrence through regulation of EMT genes (including low E-cadherin, high vimentin, and high $\mathrm{N}$-cadherin expression) after local ablation therapy (LAT) [90]. Data from a functional assay established that knockdown of CD44 significantly reduces migration and invasion via repression of the ERK/Snail pathway, subsequently leading to decreased metastasis upon tail vein injection of KD CD44 of HCC cells into a metastatic mouse model [41]. CD44 is often combined with other CSC markers to enrich hepatic CSC populations, including CD133 and EpCAM. Upon knockout of CD44 in HCC, both CD133 and EpCAM are significantly downregulated [88]. Additionally, overexpression of the $\mathrm{CD} 133^{+} \mathrm{CD} 44^{+}$population in HCC cells promotes stem/progenitor cell properties, including extensive proliferation, self-renewal, differentiation, and increased resistance to chemotherapeutic agents, via upregulation of $A B C$ transporters (ABCB1, $A B C C 1$, and $A B C G 2$ ) [21]. CD44 influences differentiated cells that experience carcinogenic insult to become proliferative cancer progenitors via activating AKT signaling and promoting Mdm2 translocation into the nucleus, with subsequent termination of the p53 response. In other words, HCC cells undergo DNA damage to escape p53-induced death and senescence and respond to proliferative signals that promote mutation and transmission to daughter cells that go on to become HCC progenitors [91]. Interestingly, an earlier study showed no correlation of CD44 with clinicopathological parameters in tumor tissues, with no differences in disease-free survival rates relative to the control group. However, in non-tumor tissues, the disease-free survival rate in the CD44-low expression group was significantly longer, compared to the CD44-high expression group. These initial findings clearly suggest that CD44 in non-tumor tissues is potentially associated with risk of tumor recurrence after hepatic resection for HCC [92].

\section{6. $C D 13$}

CD13 (Aminopeptidase N) is a membranous glycoprotein and an extracellular peptidase, the major function of which is cleavage of single neutral amino acid from the $\mathrm{N}$ terminus of small peptides. However, CD13 plays a different kind of function and substrate depending on where it is expressed. For example, CD13 in the brain cleaves opioid peptide and enkephalins to regulate neuronal signaling. In the intestine, CD13 plays a critical role in cleaving peptides in the final digestion and resorption [93]. CD13 also acts as a candidate liver cancer stem cell marker. Microarray analyses have identified CD13 as an important candidate surface marker of the side population (SP) fraction. The CD13 ${ }^{+}$ population was mainly detected in the G0/G1 phase and comprised dormant or slow-growing cancer cell populations correlated with chemoresistance through $\mathrm{ABC}$ transporter expression and recurrence. Additionally, CD13 is localized predominantly in the G0/G1 phase of the cell cycle, suggesting a role as a marker of the dormant or semi-stationary status of LCSCs [43]. Similar to CD44, CD13 could combine with other surface markers, including CD133 or CD90, and effectively initiate tumor formation, leading to increased HCC tumorigenesis [43]. $\mathrm{CD} 13^{+} \mathrm{CD} 133^{+}$and $\mathrm{CD} 13^{+} \mathrm{CD} 90^{+}$cells are reported to enhance not only HCC tumor initiation but also genotoxic chemoresistance to doxorubicin (DXR) and fluorouracil $\left(5^{\prime} \mathrm{Fu}\right)$. Treatment with both DXR and 5'FU increased the CD13 population and subsequently reduced ROS-induced DNA damage after genotoxic stress along with inhibition of HCC apoptosis. [43]. TGF- $\beta$-induced EMT phenotypes and tumorigenicity in HCC are associated with elevated CD13 expression. Flow cytometry analyses have shown that cells positive for N-cadherin, an EMT marker, are localized in CD13-positive cell fractions, suggesting that TGF- $\beta$ elicits both $\mathrm{N}$-cadherin and CD13 expression. Additionally, CD13 could metabolize TGF- $\beta$ /EMT-induced ROS and facilitate cell survival through evasion apoptosis, contributing to drug resistance [94]. Interestingly, CD13 can be induced not only by genotoxic chemotherapeutic agents but also by sorafenib in human HCC cells. Mechanistically, CD13 ${ }^{+}$CSCs are dependent on Tyr metabolism, rather than glucose, as an energy source. Simultaneously, Tyr metabolism produces nuclear acetyl-CoA. Stabilization and acetylation of Foxd3 are regulated by increasing CBP acetyltransferase activity through activation of the ERK1/2 signaling pathway [44]. Clinical data suggest that CD13 expression is correlated with that 
of EMT markers, such as E-cadherin and vimentin. Both disease-free and overall survival curves in high CD13 expression groups were significantly poorer than those of low CD13 expression groups. In view of the collective data on the association between CD13 and EMT markers, CD13 may serve as a prognostic marker of early recurrence after surgery [95].

\section{7. $C D 90$}

CD90 (Thy-1) is a glycophosphatidylinositol (GPI)-anchored protein that is expressed in a variety of cell types, including T-cells activation [96], thymocytes, neurons outgrowth modulation [97], endothelial cells, the vesicular release of neurotransmitter at the synapse [98], astrocyte adhesion [99] and fibroblasts. In addition, CD90 is also involved in cytoskeleton organization, cell migration, and inflammation. CD90 is not only implicated in the tumorigenic and metastatic capacities of various HCC cell lines but also serves as a marker of LCSCs [45]. CD90 cell populations have been isolated from both HCC specimens and blood samples of liver cancer patients and could initiate tumor nodule formation following intrahepatic injection into SCID/beige mice and subsequent secondary and tertiary transplantation into immunodeficient mice. These findings support the utility of CD90 as a surface marker for diagnosis of HCC malignancy [100]. Gene expression analysis of sorted cells has disclosed different features of EpCAM and CD90 populations. EpCAM possesses characteristics of epithelial cells while CD90 contains vascular endothelial cell features. Moreover, these markers are correlated with different clinicopathological parameters. Upon transplantation into xenografts, $\mathrm{EpCAM}^{+}$cells promoted tumor growth in subcutaneous lesions and $\mathrm{CD}^{+} 0^{+}$cells induced high metastatic capacity in lung cells. Furthermore, CD90 influenced $\mathrm{EpCAM}^{+}$cell motility through activation of the TGF- $\beta$ pathway [61]. Cyclin D1 overexpression promoted stemness properties and enhanced chemoresistance through increasing $\mathrm{CD}^{+} 0^{+}$and $\mathrm{EpCAM}^{+}$populations. Mechanistically, cyclin D1 interacted with and activated Smad2/3 and Smad4 signaling pathways to regulate LCSC self-renewal [48]. Circulating tumor stem cell (CTSC) populations within circulating tumor cells (CTC) play critical roles in the formation of distal metastatic tumors [101]. CD $90^{+} \mathrm{CXCR} 4^{+}$present a better surface marker of CTSCs than $\mathrm{CD} 133^{+} \mathrm{CD} 90^{+}$, promoting the formation of tumor spheres in vitro, tumor development in primary and subsequent secondary and tertiary transplantation experiments, and distal metastatic tumors following subcutaneous transplantation [62]. Analysis of clinical HCC patients confirmed that CD90 is an important surface marker that is positively correlated with a number of clinicopathological parameters, including histopathology grade and tumor size. Additionally, CD90 expression is significantly associated with early recurrence and short-term survival of HCC patients [102,103]. Experiments on human tissue samples and JHH-6 HCC cell lines indicate that CD90 is significantly overexpressed in tumors and positively associated with growth factors, including hepatocyte growth factor (HGF), fibroblast associated protein (FAP), and alpha smooth muscle actin 2 (ACTA2). Moreover, CD90 induces chemoresistance to doxorubicin through reducing ABCB1 and increasing the $\mathrm{ABC}$ transporter proteins ABCG2 and Oct4, [46,47]. CD90 expression has been detected in not only LCSCs but also tumor-associated fibroblasts (CAFs). CD90 is positively correlated with clinicopathologic characteristics, including pathological grade, satellite lesions, PVTT, and recurrence, suggesting a role as a predictor of poor prognosis in CAFs, and is consistently determined as a reliable biomarker for prognosis of HCC patients subjected to hepatic resection [104].

\section{8. $C D 24$}

CD24 is a mucin-like cell surface glycoprotein expressed in stem/progenitor cells and a variety of human malignancies, including hepatocellular carcinoma, breast cancer, renal cell carcinoma, colon cancer, B-cell lymphoma, differentiating neuroblasts, small cell and non-small cell lung carcinoma, and nasopharyngeal carcinoma. In addition, CD24 plays an important role in regulating neural development by contributing to the downstream signaling network by glycosyl- phosphatidylinositol (GPI) link to the cell surface [105]. CD24 expression has been reported in undifferentiated bipotential mouse embryonic liver stem and 3,5-diethoxycarbonyl-1,4-dihydrocollidine-treated oval cells and can 
help differentiate progenitor/stem cells from normal adult liver. Moreover, CD24 enhances expression of CK19, epithelial cell adhesion molecule, Sox 9, and FN14, which facilitate differentiation into hepatocytes [106]. These earlier studies suggest that CD24 is involved in metastasis, differentiation, self-renewal, and chemoresistance of HCC cells. Consistent with these findings, CD24 expression was shown to be positively correlated with metastasis in the HCC cell lines MHCC97H and HCCLM3, which display enhanced proliferation, migration, and invasive properties through increasing the CD24 population. Moreover, CD24 expression is associated with tumor number, tumor size, vascular invasion, encapsulation, differentiation, satellite lesions, and poor TNM stage in overall and relapse-free survival. CD24 is positively associated with PCNA and $\beta$-catenin, correlated with clinicopathologic features, including low AFP levels, and confers a greater propensity for multiple tumors and liver cirrhosis. Simultaneously, CD24 expression influences type II and III tumor recurrence. Taken together, the data clearly support the value of CD24 as a prognostic factor for HCC after surgery [49]. CD24 is proposed to play an important role in tumor-initiating cells (T-ICs) from chemoresistant (cisplatin) hepatocellular carcinoma (HCC) xenograft tumors orthotopically transplanted into SCID mice, promoting tumor-forming and self-renewal abilities through phosphorylation of STAT3 and induction of NANOG expression. mRNA microarray analyses further showed that the CD24 level is increased in chemoresistant groups despite no changes in other liver T-IC markers, including CD133, CD90, and EpCAM [50]. In an earlier investigation, $\mathrm{CD} 24^{+}$cells were isolated from two patient samples, followed by injection of $4000 \mathrm{CD} 24^{+}$cells into NOD/SCID mice, which led to higher tumor development capability than $\mathrm{CD} 24^{-}$cells, supporting the tumorigenic property of CD24 [50]. In addition, CD24 induced resistance to both cisplatin and sorafenib. CD24 is more highly expressed in sorafenib-resistant relative to untreated wild-type cells, conferring greater resistance through activating autophagy and inhibiting the AKT/mTOR signaling pathway [51]. CD24 ${ }^{+}$LCSCs display enhanced levels of inducible nitric oxide synthase (iNOS), which triggers the Notch1 signaling pathway in a manner dependent on cGMP/PKG-mediated activation of TACE and upregulation of iRhom-2, further promoting self-renewal and tumor growth properties [52].

\section{9. $\mathrm{OV}-6$}

OV-6 is a monoclonal antibody raised against cells isolated from carcinogen-treated BALB/c mouse liver $[53,107]$. The OV-6 population obtained from HCC cell lines and primary HCC tissues acts as a hepatic progenitor marker [108] and promotes self-renewal with endogenous activation of Wnt $/ \beta$-catenin signaling. In other words, OV-6 expression is enriched in tumor cells via Wnt activation while inhibition of $\beta$-catenin signaling decreases the OV- $6^{+}$population in HCC. Moreover, $\mathrm{OV}^{+}{ }^{+} \mathrm{HCC}$ cells display enhanced resistance to chemotherapeutic drugs, such as cisplatin [53]. OV6 promotes HCC tumors and leads to increased self-renewal capacity, tumorigenicity, and invasive and metastatic properties through positive correlation with C-X-C chemokine receptor type 4 (CXCR4) and its specific ligand, CXCL12 (SDF-1) [109]. The same research group proposed that HBx influences HCC self-renewal, stem cell-associated gene expression, tumorigenicity, and chemoresistance through stem-like properties of the $\mathrm{OV}^{+}$population. In terms of the underlying mechanism, HBx directly interacts with MDM2 to form a protein complex and subsequently inhibits MDM2 ubiquitin-directed self-degradation. Translocation of the HBx-MDM2 complex into the nucleus enhances transcriptional activity and expression of CXC4 and CXC12 and subsequent activation of the $\mathrm{Wnt} / \beta$-catenin signaling pathway promotes the stem-like properties of $\mathrm{OV}^{+} \mathrm{CSC}$ in liver [54].

\subsection{Side Population Cells}

Side population (SP) cells are originally shown to be enriched in stem cell compartments of various tissues and organs $[110,111]$. Subsequently, SP cells were detected in hepatocellular carcinoma cell lines, including Huh7 and PLC/PRF/5, using Hoechst 33342 dye staining in flow cytometry. The results suggested that SP cells may effectively serve as markers to distinguish between LCSCs and HCC cells and initiate tumorigenesis by upregulating stemness genes along with tumor formation in xenograft 
transplant experiments [112]. Microarray analysis of HCC cell lines demonstrated that other genes are additionally influenced in SP, compared with non-SP cells, such as GATA6 which is associated with embryonic development and hepatocytic differentiation and some $\mathrm{ABC}$ transporter genes, including ABCG2, ABCB1, and CEACAM6, linked to chemoresistance to doxorubicin, 5-fluorouracil, and gemcitabine, in addition to epithelial and mesenchymal markers. SP cells are therefore potentially involved in differentiation, chemoresistance, and metastasis of HCC [24,55]. Among these, ABCG2 in HCC cell lines is particularly significant. Flow cytometry experiments to isolate the ABCG2+ subpopulations of HCC cell lines sub-cultured for 4 weeks revealed the presence of both $\mathrm{ABCG}^{+}$and ABCG2- progenies, supporting critical roles of ABCG2 in maintenance of the cancer cell hierarchy of HCC [113]. The researchers further showed intrinsic expression of ABCG2 in HCC tissues and cell lines. Furthermore, ABCG2 is reported to significantly influence drug efflux-related chemotherapy resistance in SP cells by altering subcellular localization through activation of the Akt signaling pathway [23].

\subsection{1. $C D 47$}

CD47 is a transmembrane member of immunoglobulin, also as an integrin-associated protein (IAP), which is the expression in platelets, and binds to the signal-regulatory-protein- $\alpha$ (SIRP $\alpha$ ) followed by inhibition of phagocytosis $[57,114]$. CD47 has been indicated to not only play an important role in immune evasion but to also regulate tumor apoptosis, angiogenesis, metastasis, tumor-initiating ability, chemoresistance, and proliferation in many cancers, including HCC. CD47 is overexpression in the HCC tumor cells and positively correlates with $\mathrm{CD}^{+} 8^{+}$(which is a macrophages marker) expression. Further, the results suggested that IL-6 derives from tumor-infiltrating macrophages that can induce CD47 expression in HCC by activation of the STAT3 signaling pathway. In addition, the same group also suggested that blocking of CD47 and combination with chemotherapeutic drugs enhance macrophage-mediated phagocytosis, which means lower expression of CD47 benefits the treatment with adjuvant transcatheter arterial chemoembolization (TACE) of HCC patients [58]. In addition, CD47 is one of the TICs markers, which shows the highest overexpression compared to other TICs markers in the sorafenib resistance cells. Both the clinical HCC sample and sorafenib resistance suggested positive correlations between NF- $\mathrm{KB}$ and CD47. CD47 is regulated by NF- $\mathrm{KB}$, which can specifically bind to the CD47 promoter, and then up-regulation CD47 transcription activity follows [56]. CD47 in HCC is one of the LCSCs that has been developed of antibodies and widely studied. CD47 is blocked by an anti-CD47 monoclonal antibody, causing not only inhibition of self-renewal, tumorigenicity, migration, and invasion abilities but also synergizes in combination with chemotherapeutic drugs, including doxorubicin and cisplatin [115].

\section{Interactions of LCSCs Influencing HCC and Therapeutic Strategies}

\subsection{The Wnt/ß-Catenin Pathway}

Wnt $/ \beta$-catenin signaling is highly and evolutionarily conserved in normal cells and participates in tissue homeostasis [116]. The canonical Wnt/ $\beta$-catenin pathway is critical for HCC progression and tumorigenesis. $\beta$-catenin is a functional protein that plays a dual role in cell-cell adhesion and gene transcription and serves as an intracellular signal transducer in the Wnt signaling pathway [117-120]. Moreover, $\beta$-catenin is one of the subunits of cadherin that binds E-cadherin. However, mutation and overexpression of $\beta$-catenin promotes tumor progression in many cancer types, including hepatocellular carcinoma [121]. Under normal conditions, $\beta$-catenin in the cytosol is marked for ubiquitin-mediated proteolysis by specific phosphorylation of serine residues through an enzymatic complex including adenomatous polyposis coli (APC), Axin, and the kinases glycogen synthase kinase- $3 \beta$ (GSK-3 $\beta$ ) and casein kinase I [122]. Wnt protein directly interacts with cell surface Frizzled receptors and LRP5/6 co-receptors upon activation of the Wnt/ $\beta$-catenin pathway. Immediately after this step, Dishevelled protein is activated and released, leading to formation of the destructive enzymatic APC/Axin/GSK-3 $\beta$ complex and inhibition of GSK-3 $\beta$. Further accumulation and stabilization leads to 
$\beta$-catenin translocation from the cytoplasm to nucleus and subsequent binding to TCF/LEF proteins, which activates downstream target genes, including MMP3, MMP7, ADAM10, Twist, Slug, Tiam1, c-Myc, cyclin D1, and fibronectin (Figure 2A) [123,124]. Frequent hyperactivation of the Wnt/ $\beta$-catenin pathway in HCC patients leads to accumulation of $\beta$-catenin in tissue and nucleus, which serves as a hallmark of Wnt signaling. Activation of $\mathrm{Wnt} / \beta$-catenin signaling has been shown to promote self-renewal, differentiation, and invasiveness in LCSCs $[30,63,70,71]$. Inhibition of Wnt/ $\beta$-catenin signaling via small-molecule inhibitors reduces expression of Wnt and $\beta$-catenin proteins in LCSCs and further suppresses HCC stemness. One identified small-molecule inhibitor of Wnt $/ \beta$-catenin signaling is CWP232228, an antagonist that competes with $\beta$-catenin for binding to TCF in the nucleus and suppresses transcriptional activity of downstream genes. This compound inhibits HCC self-renewal and tumor initiation through suppression of gene (Oct4, KLF4, Nanog, and SOX2) and surface marker $\left(\mathrm{CD}_{133}{ }^{+} / \mathrm{ALDH}^{+}\right)$expression of LCSCs (Figure 2A.) [125]. FH535 is another antagonist that inhibits the Wnt $/ \beta$-catenin signaling pathway and peroxisome proliferator-activator receptor (PPAR $\gamma$ and PPAR $\delta$ ) signaling [126]. This compound suppresses proliferation and motility of HCC cells through significant downregulation of cyclin D1 and MMP9 mRNA [127]. Additionally, FH535 is a potent therapeutic inhibitor that, upon combination with Sorafenib, exerts synergistic inhibition of proliferation and induction of apoptosis via enhancing cleaved poly (ADP-ribose) polymerase (PARP), inhibiting cyclin D1, Bcl-2, survivin, and c-MYC levels and reducing both mitochondrial respiration and glycolytic rates to disrupt the bioenergetics of HCC/LCSC cells $[128,129]$. WM130, a derivative of matrine, a Sophora alkaloid, has been shown to exert better pharmacological activities and anticancer effects against HCC than its parent compound. Results to date suggest that WM130 suppresses proliferation and self-renewal capability in both HCC and doxorubicin-resistant hepatoma cells by decreasing phosphorylation of GSK3 $\beta$ and subsequent degradation of $\beta$-catenin through downregulation of the CSC biomarker, EpCAM, and other stemness-related genes. Additionally, combined treatment with WM130 and doxorubicin synergistically inhibits tumor growth [130]. WM130 not only influences proliferation but also inhibits invasion and migration and induces apoptosis of HCC cells via suppression of EGFR/ERK/MMP-2 and PTEN/AKT signaling pathways [131]. Another inhibitor derived from matrine, (6aS, 10S, 11aR, 11bR, 11cS)-10- methylamino-dodecahydro- 3a,7a-diazabenzo (de) (MASM), inhibits the PI3K/AKT/mTOR and AKT/GSK3 $\beta / \beta$-catenin pathways, with subsequent reduction of Bcl-2 and cyclin D1 expression along with increased PARP cleavage and p27 expression, and markedly reduces the $\mathrm{EpCAM}^{+} / \mathrm{CD}_{13} 3^{+}$cell population. These combined effects achieve inhibition of cell proliferation, induction of apoptosis, and cell cycle arrest, in addition to suppression of xenograft tumor growth for HCC [132]. Two anti-FZD antibodies are currently in clinical trials. One is OMP-18R5, which can interact with 5 out of 10 FZD receptors and competitively block Wnt3A interactions with FZD receptors. This compound has been shown to suppress tumor growth in a mouse model and exerts a greater inhibitory effect on tumor growth and delay in tumor recurrence in combination with a chemotherapeutic agent. OMP-18R5 has recently been evaluated in phase 1 clinical trials in patients with lung, breast, and pancreatic cancer [133]. The other preclinical anti-FZD antibody is OMP-54F28, a truncated FZD8 receptor fused to the IgG1 Fc region that competes with Fzd8 receptor for ligand binding, leading to suppression of the Wnt/ $\beta$-catenin signaling pathway, inhibition of solid tumor growth, and decrease in CSC frequency, either alone or in combination with other chemotherapy drugs, such as gemcitabine [134]. Evaluation of the safety and pharmacokinetics/pharmacodynamics of OMP-54F28 combined with sorafenib in HCC patients has been completed in phase $1 \mathrm{~b}$ clinical trials (ClinicalTrials.gov identifier: NCT02069145) [133]. The results suggested that the success of providing completed the safety and pharmacokinetics/pharmacodynamics of FZD-targeted therapy in HCC patients in phase 1 trials as well as suggested potential combinations of FZD-targeted and FDA-approved targeted therapy in HCC patients. 


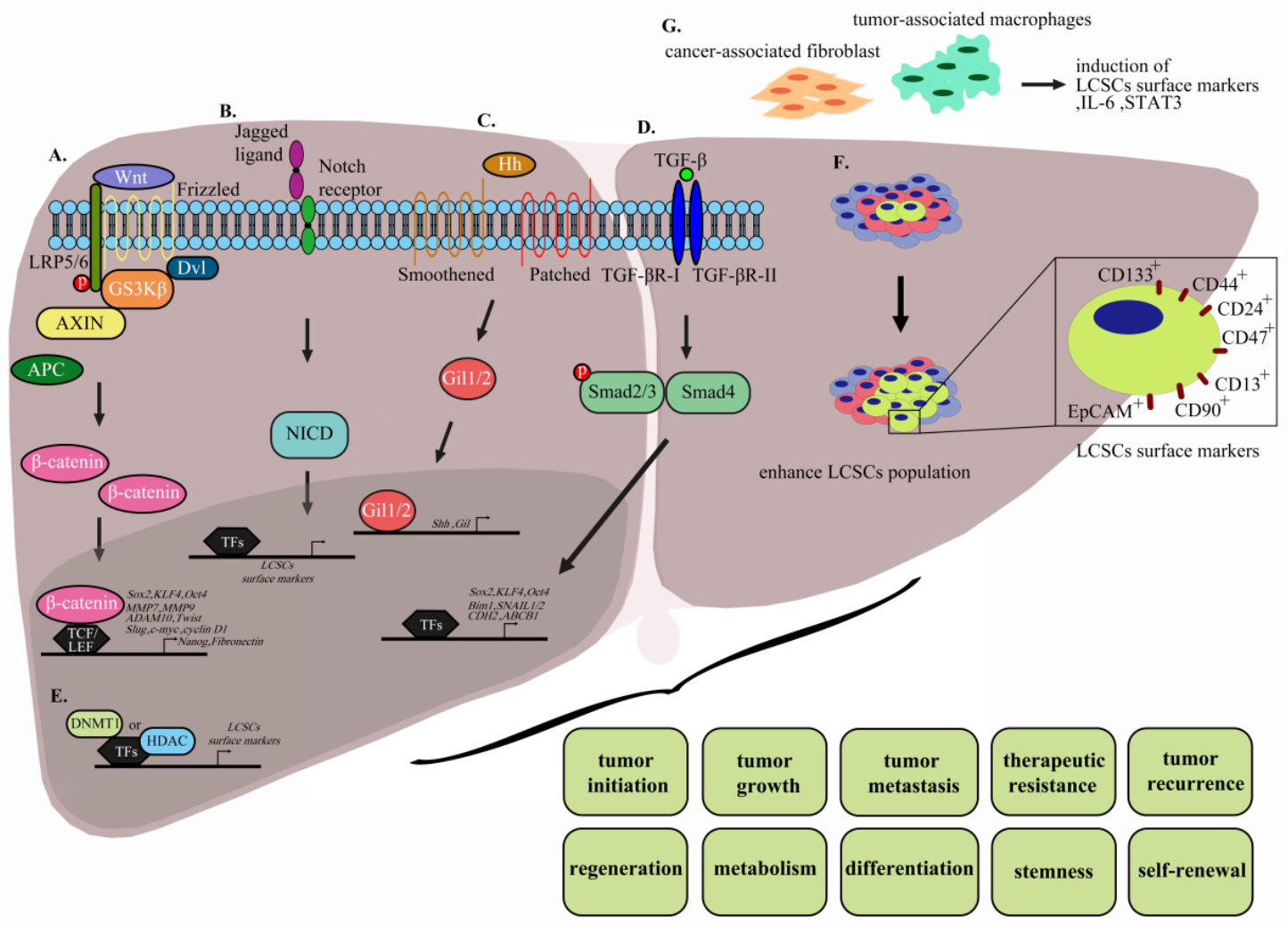

Figure 2. Interactions of LCSCs influencing HCC. (A) The Wnt protein directly interacts with cell surface receptor Frizzled and LRP5/6 co-receptors for activation of the Wnt/ $\beta$-catenin pathway. Immediately after, Dishevelled protein is activated and released, leading to the generation of destructive enzymatic complex (APC/Axin/GSK-3 $\beta$ ) and inhibition of GSK-3 $\beta$. Following accumulation and stabilization, $\beta$-catenin translocates from the cytoplasm to the nucleus and subsequently binds TCF/LEF proteins to activate transcription of downstream target genes, including MMP3, MMP7, ADAM10, Twist, Slug, Tiam1, c-Myc, cyclin D1, and Fibronectin. (B) Ligand binding to NOTCH leads to cleavage and release of the Notch intracellular domain (NICD), promoting transcription factor complex (CBF1/RBPjk/Su(H)/Lag1 (CSL)) translocation from the cytoplasm to nucleus and activation of downstream target genes. (C) Desert hedgehog (DHH), Indian hedgehog (IHH), or Sonic hedgehog (SHH), the ligands binding PTCH1 or PTCH2, promote SMO localization to primary cilium on the cell membrane. Subsequently, glioma-associated oncogene homolog (GLI), a transcription factor, translocates to the nucleus and activates transcription of downstream genes. (D) Interactions with ligand stabilize T $\beta$ RI and T $\beta$ RII, following which T $\beta$ RII phosphorylates the GS domain of T $\beta$ RI, leading to further activation. Subsequent recruitment of intracellular SMAD proteins and translocation to the nucleus stimulate downstream gene transcription. (E) DNA methylation transferase (DNMT1) and histone deacetylases (HDAC) act as key epigenetic regulatory factors for downstream gene transcription. (F) Enhancement of surface markers of LCSC populations, including EpCAM, CD133, CD44, CD24, CD13, CD90, and CD47. (G) Cancer-associated fibroblast (CAFs) and tumor-associated macrophages (TAMs) promote LCSC surface marker populations (IL-6 and STAT3) within the microenvironment.

\subsection{Notch Signaling}

The Notch pathway is a highly conserved cell signaling mechanism in multicellular organisms that regulates proliferation, maintenance of stem cells, differentiation, neurogenesis, embryonic development, maintenance of adult tissue homeostasis, and angiogenesis. The Notch receptor is a single-pass transmembrane receptor protein composed of functional extracellular (NECD), transmembrane (TM), and intracellular (NICD) domains. The protein exists as four isoforms, designated NOTCH1, NOTCH2, NOTCH3, and NOTCH4 [135,136], which interact with transmembrane ligands, such as Delta and Serrate, on neighboring cells. Ligand binding to NOTCH triggers 
cleavage and release of the Notch intracellular domain (NICD) and promotes translocation of the transcription factor complex (CBF1/RBPjk/Su(H)/Lag1 (CSL)) from the cytoplasm to nucleus, in turn, stimulating downstream target gene transcription (Figure 2B) [137]. Tumor progression, self-renewal, and CSC differentiation are influenced by Notch signaling, which is activated in most types of cancer. Accumulating research has focused on eliminating CSCs via targeting Notch signaling as a therapeutic strategy for cancer [137]. Several LCSC-related proteins, including CD90, Notch1, Nanog, and Sox2, which are overexpressed in parenchymal hepatic cells, have been identified via IHC. However, only CD90 was exclusively detected in HCC patient samples, supporting a correlation of this biomarker with poor prognosis. Isolated $\mathrm{CD} 90^{+}$populations from HCC cell lines were subsequently shown to exhibit increased tumorigenicity, chemoresistance, tumor invasion, and metastasis through Notch signaling activation. Moreover, the Notch signaling pathway promoted self-renewal, invasion, and migration of $\mathrm{CD}^{-} 0^{-}$cells. The collective data suggest that CD90 is an effective biomarker for LCSCs and specifically upregulates stem-associated genes Nanog, Oct4, and Sox2 through activated Notch signaling [138]. C8orf4 deletion promotes nuclear translocation of N2ICD and subsequently triggers Notch2 signaling, which enhances CD133 ${ }^{+} / \mathrm{CD}_{1} 3^{+}$expression and sustains LCSC stemness [139]. Notch3 is overexpressed in HCC patients and positively correlated with clinicopathological parameters, including alpha-fetoprotein (AFP) levels, poor prognosis (shorter survival time), and cisplatin resistance. Moreover, high Notch3 is correlated with lower expression of $\beta$-catenin but higher aldehyde dehydrogenase (ALDH) activity, supporting the theory that Notch3 regulates tumor stemness through inactivation of Wnt/ $\beta$-catenin [140]. Notch and Wnt/ $\beta$-catenin signaling pathways are intercalated and play critical roles in stemness characteristics and metastasis of LCSCs. Notch1 is upregulated and activates Notch1 intracellular domain (NICD) expression in HCC through $W n t / \beta$-catenin signaling. Treatment with the Wnt $/ \beta$-catenin-specific tankyrase $1 / 2$ inhibitor (XAV939) and $\gamma$-secretase inhibitor (DAPT) that block the Wnt/ $\beta$-catenin and Notch signaling pathways, respectively, leading to suppression of tumor growth [141]. PF-03084014 is a $\gamma$-secretase inhibitor that blocks self-renewal and proliferation of cancer stem cells. The compound has been shown to reduce both hepatocellular carcinoma tumors growth and metastasis in sphere-derived orthotopic tumor model and one patient-derived xenograft (PDX) model. Additionally, low-dose PF-03084014 induces sphere differentiation of hepatocellular carcinoma and further reduces chemoresistance, supporting its value as a novel antitumor and antimetastatic therapeutic agent for HCC [142].

\subsection{Hedgehog Signaling Pathway}

The hedgehog signaling $(\mathrm{Hh})$ pathway facilitates normal development of mammalian embryos and regulates cell proliferation, survival, and differentiation. Hh is limited to stem cell subsets that undergo rapid turnover and modulate tissue repair in adult tissue, such as nervous system, skin, and intestines [143-146]. The canonical Hh pathway is activated by three ligands, specifically, Desert hedgehog (DHH), Indian hedgehog (IHH), and Sonic hedgehog (SHH), which interact with the 12-pass transmembrane protein receptors Patched 1 (PTCH1) and Patched 2 (PTCH2). In the absence of ligand, Smoothened (SMO), a 7-pass transmembrane G-protein-coupled signal transduction molecule, is localized in vesicles. Ligand binding to PTCH1 or PTCH2 promotes SMO localization to primary cilium on the cell membrane. This step initiates translocation of glioma-associated oncogene homolog (GLI), a transcription factor, to the nucleus and subsequent activation of the downstream genes GLI1, PTCH1, cyclin D, VEGF, and c-myc (Figure 2C). However, upon overexpression of Hh ligands, loss of function of the receptor or abnormal transcription factor expression leads to dysregulation of the Hh pathway and further initiation and progression of multiple cancer types, including breast cancer, prostate cancer, hepatocellular carcinoma, pancreatic cancer, and brain cancers [147]. In clinical HCC cases with both HBV infection and HBx transgenic mice (HBxTg), correlations with Hh marker upregulation have been reported. Therefore, blocking the Hh signaling pathway may inhibit HBx-induced migration, anchorage-independent growth, and HBxTg tumor development [148]. A number of studies have shown that Hh markers are overexpressed in HCC patients and positively correlated with clinicopathological 
parameters (tumor differentiation, encapsulation, vascular invasion, early recurrence, and intrahepatic metastasis) along with significantly poorer overall and disease-free survival $[149,150]$. Dysregulation of Hh signaling contributes to maintenance of stemness in CSCs and influences tumor growth, metastasis, drug resistance, and differentiation [151]. In a highly tumorigenic $\mathrm{CD} 133^{+}$population of HCC, Smoothened (SMO) is abundantly expressed in association with the Hh signaling pathway and influences liver cancer stemness maintenance [35]. Current development of therapeutic agents that target Hh signaling has primarily focused on natural and synthetic antagonists of SMO and GLI1, which have undergone clinical trials with varying degrees of success [152]. Cyclopamine, an isolate of V. californicum, was initially shown to inhibit the Hh pathway by direct binding to SMO [153]. Cyclopamine inhibits tumor proliferation and growth in multiple cancer types, including HCC. The compound is reported to suppress Hep3B hepatocarcinogenicity by inhibiting SMO and blocking overactivation of Hh signaling by $50 \%$, along with decreasing c-myc transcription activity [154]. However, cyclopamine-induced reduction of tumor growth is associated with several adverse side effects, including weight loss, dehydration, and death, in a mouse model $[155,156]$. GDC-0449, a second-generation cyclopamine, also directly binds SMO to prevent GLI activation with subsequent inhibition of the Hh pathway [157]. The compound was approved by the FDA as the first Hh signaling inhibitor for treatment of primary or recurrent cancers. GDC-0449 induces a significant decrease in liver myofibroblasts, progenitors, and liver fibrosis through inhibitory effects on Hh signaling, leading to suppression of HCC metastasis with no adverse effects on mortality [158]. These results support the utility of GDC-0449 as a safe clinical therapeutic agent for cancer. Moreover, activation of Hh signaling enhances the liver macrophage-mediated proinflammatory response and critical progression of nonalcoholic fatty liver disease (NAFLD). The overall findings clearly indicate that GDC-0449 and LED225 effectively reduce macrophage activation and proinflammatory cytokine expression (TNF- $\alpha$, IL-1 $\beta$, MCP1, and IL-6) as well as further NAFLD progression through direct binding to SMO and blocking of the Hh signaling pathway, supporting their potential utility as effective therapy for NAFLD-induced liver cancer [159]. LDE-225 is a second-line treatment agent for cancer approved by the FDA that exerts its effects by inhibiting the Hh signaling pathway. Data from Phase I/II clinical trials support the efficacy of LDE-225 as both monotherapy and combination therapy for numerous solid or hematological malignancies, including hepatocellular carcinoma (HCC) and Child-Pugh A cirrhosis (CPA). Phase I trial results indicate that the maximum safe dose of LDE-225 can be used to effectively treat advanced or metastatic HCC and CPA (ClinicalTrials.gov Identifier: NCT02151864). GANT-61 is a Gli transcription inhibitor that modulates genes involved in cell proliferation, self-renewal, and metastasis, resulting in suppression of pancreatic CSC characteristics and tumor growth. The compound is reported to show efficacy as a chemotherapeutic agent for human pancreatic cancer by regulatory activity on apoptosis markers [160]. The above studies have reported that the Hh signaling pathway is activated in HCC and effectively targeted by related small-molecule inhibitors for therapeutic purposes. Additionally, the group of Wang [161] showed that GANT61 induces autophagy that contributes to apoptosis and, further, suppression of HCC tumor growth. Clearly, autophagy plays an important role in determining the response to Hh-targeted therapies for HCC.

\subsection{TGF- $\beta$ Signaling Pathway}

TGF- $\beta$ family ligands not only play critical roles in cell proliferation, growth, homeostasis, and differentiation but also influence self-renewal of many stem cell types. TGF- $\beta$ proteins initiate intracellular signaling by binding to the surface protein complexes of transmembrane kinases, which can distinguish between T $\beta$ RI and T $\beta$ RII. Interactions with ligand stabilize both T $\beta$ RI and T $\beta R I I$. Subsequently, T $\beta$ RII phosphorylates the GS domain of T $\beta$ RI, leading to its activation. Subsequent recruitment of the intracellular SMAD protein and translocation to the nucleus triggers downstream gene transcription (Figure 2D) [162]. TGF- $\beta$ plays a dual role in liver cancer development, acting as a tumor suppressor at the early stages while promoting metastasis in the late stages of cancer 
progression $[163,164]$. Tumor-associated macrophages (TAM), a critical component of immune cells in the tumor microenvironment are positively correlated with the $\mathrm{EpCAM}^{+}$population and enhance cancer stem cell-like properties via upregulation of CSC transcription factors Bmi1 and Klf4. However, blockage of TGF- $\beta$ expression using anti-TGF- $\beta$ antibodies significantly inhibits stem cell-like behavior via downregulation of Bmi1 and Klf4 transcription [165]. In addition, TGF- $\beta$ displays the capability to induce CD133 and further promotes tumor initiation upon subcutaneous inoculation into nude mice [166]. LY2157299, also known as galunisertib, specifically inhibits TGF- $\beta$ receptor (T $\beta R$ )-I activation and exerts anti-proliferative and anti-invasive effects against HCC. Treatment of IHC with LY2157299 reduced expression of the proliferation marker, Ki67, and induced that of caspase-3, an apoptosis marker. In patient samples, LY2157299 could effectively inhibit proliferation and induce apoptosis upon administration as both monotherapy and in combination with Sorafenib. LY2157299 has been shown to exert synergistic therapeutic effects with Sorafenib [167]. However, the utility of LY2157299 in LCSCs remains to be established. Furthermore, a number of small-molecule inhibitors of TGF- $\beta$ signaling have been developed with a specific focus on Smad protein, which effects LCSCs expression in HCC. GP73 is reported to enhance Smad2/3 phosphorylation via activation of TGF- $\beta 1$ and promote EMT via upregulation of EMT marker expression while SB431542 specifically inhibits Smad2/3 phosphorylation and reverses EMT in HCC [168]. Cyclin D is dependent on activation of Smad2/3 and Smad4, leading to enhancement of single sphere formation, $\mathrm{CD}^{+} 0^{+}$and $\mathrm{EpCAM}^{+}$ populations, stemness gene expression, and chemoresistance (Figure 2D). Smad inhibitors impaired cyclin D-induced self-renewal, enhanced sensitivity to chemotherapy, and suppressed tumor growth in a cyclin D sphere-derived xenograft model [48].

\subsection{Targeting of LCSC Surface Markers}

Several therapeutic surface markers have been identified to date. CD133 is a surface marker isolated from tumor-initiating cells (TICs), which is significantly correlated with poor prognosis of HCC patients. Two types of oncolytic measles viruses (MV), MV-141.7 and MV-AC133, have been described that target CD133 and selectively destroy $\mathrm{CD} 133^{+}$tumor cells [169]. Moreover, enhanced oncolytic activities and prolonged survival of CD133-targeted viruses in clinical trials, compared with parental MV-Nse, support their close association with oncolytic agents. VB4-845, a recombinant fusion protein, is an anti-EpCAM single-chain antibody. In eight HCC cell lines, VB4-845 strongly suppressed sphere formation ability, compared to 5-FU. In addition, in high EpCAM ${ }^{+}$ expressing cell populations, VB4-845 suppressed cells expressing CD133 and CD13 while treatment with 5'FU induced CD133- and CD13-positive populations [170]. Evaluation of VB4-845 in clinical trials for various cancer types, including urothelial carcinoma, bladder cancer, squamous cell cancer, and head-and-neck cancer, support its therapeutic efficacy for HCC [171]. Isolated CD $90^{+} \mathrm{CD} 44^{+}$cells from HCC displayed better tumorigenic capacity than $\mathrm{CD} 90^{+} \mathrm{CD} 44^{-}$cells. Thus, a CD44-antibody could effectively target $\mathrm{CD} 90^{+} \mathrm{CD} 44^{+}$cell population and induce apoptosis in HCC [45]. In another study, CD44 antibody-mediated liposomal nanoparticles in HCC promoted apoptosis and reduced tumor growth through specifically targeting CD44 [172]. A further potential therapeutic strategy is development of surface marker inhibitors, such as Ubenimex, which suppress CD13 and are widely used as an immunoenhancer for treating solid tumors and hematological neoplasms. Ubenimex is reported to reverse multidrug resistance (MDR) of HCC by suppressing Pim3, BCL-2, and BCL-XL expression, decreasing Bad phosphorylation and further enhancing tumor cell apoptosis [173].

\subsection{Epigenetic Changes}

Alterations in epigenetic control of gene expression play a substantial role in disease progression, including hepatocellular carcinoma (HCC) [174]. Epigenetic modification mechanisms include DNA methylation, histone modification, and chromatin remodeling. Notably, epigenetic changes can influence activation of certain genes but not the genetic code of DNA [175-177]. Recent studies have suggested that epigenetic changes are correlated with LCSC phenotypes. For instance, suppression 
of DNA methylation via treatment with the DNMT1 inhibitor, zebularine (ZEB), induced highly tumorigenic cells within the side population (SP) fraction, leading to increased tumorigenicity of HCC [178]. Treatment of high-density cells with ZEB reduced expression of surface markers (such as CD133, CD44, EpCAM) and cancer stem cell properties as well as tumorigenesis, concomitant with upregulation of genes related to apoptosis and differentiation. Taken together, the results suggest that DNA methylation acts as a key epigenetic regulatory factor of LCSCs (Figure 2E) [179]. In clinical HCC patients, SALL4 was positively correlated with EpCAM and significant decrease in overall survival [60]. SALL4 is highly expressed in HCC and associated with elevated serum alpha-fetoprotein levels, high frequency of hepatitis B virus infection, and poor prognosis. In addition, SALL4 is reported to induce spheroid formation and upregulation of LCSC markers, including KRT19, EPCAM, and CD44, in HCC. HDAC activity was induced in SALL4-positive cells via SALL4 interactions with nucleosome remodeling and deacetylase (NuRD) complexes. The HDAC inhibitor, SBHA, may present an effective option to inhibit SALL4-positive cell proliferation [180].

\subsection{MicroRNAs and Long Non-Coding RNAs}

Evidence from a systematic review suggests that high-resolution microarray and deep sequencing techniques have encouraged studies on non-coding RNAs (ncRNAs) including short non-coding RNAs (miRNAs and sRNA) (<200 nucleotides) and long non-coding RNAs (lncRNAs) ( $>200$ nucleotides). In human plasma and tumor tissues of HCC, several miRNAs and lncRNAs that regulate LCSCs show promise as biomarkers for diagnosis and prognosis as well as response to therapy. Both miRNAs and lncRNAs can act as critical regulators of self-renewal, differentiation, and tumorigenicity of CSCs. For example, microRNA-150 upregulated in a CD133- subpopulation of HCC interacts with 3'UTR of c-myc mRNA, consequently inhibiting c-myc protein levels. Overexpression of microRNA-150 significantly reduced the $\mathrm{CD}_{133^{+}}$cell population and further inhibited cell growth and tumor sphere formation, inducing cell cycle arrest and apoptosis [181]. MicroRNA-449a is overexpressed in poorly differentiated HCC tissues, drug-resistant cell lines, and Nanog-positive liver cancer cells. Upregulation of microRNA-449a is proposed to increase stemness in HCC. Notably, knockdown of miR-449a via transcription factor 3 (TCF3) reduced Nanog transcription and influenced cellular stemness [182]. Oct4/miR-1246 in CD133 ${ }^{+}$HCC is correlated with a poor diagnosis which promotes cancer stemness through activation of the Wnt/ $\beta$-catenin pathway through miR-1246 targeting to degradation of $\beta$-catenin complexes suppressing AXIN2 and GSK3 $\beta$ expression [183]. miR-125b is down-regulated in HCC by TGF- $\beta 1$-induced and negatively correlated with LCSCs expression. Besides, in vitro and in vivo studies suggested that EMT and EMT-associated traits of HCC are inhibited by targeting SMAD2 and SMAD4 by ectopic expression of miR-125b [184]. miR-216a/217 prompted migration and metastatic ability and increased the stem-like cells population and tumor recurrence in HCC by activation of PI3K/Akt and TGF- $\beta$ pathways by induction of targeting PTEN and SMAD7 expression [185]. Recent findings by our group suggest that high $\mathrm{BC} 200$ expression in the $\mathrm{CD}_{133^{+}}$population of $\mathrm{HCC}$ promotes tumor growth and sphere formation, supporting its requirement in self-renewal and maintenance of LCSCs [186]. LncSox4 is highly expressed in HCC tissues and liver tumor-initiating cells (TICs) and required for liver TIC self-renewal and tumor initiation. LncSox4 regulates TIC self-renewal by recruiting STAT3 that binds the Sox 4 gene promoter and induces Sox4 transcription activity. Simultaneously, Sox4 is positively correlated with expression of the surface markers EpCAM and CD133 that promote TIC self-renewal [187]. Both lncRNAs and Wnt/ $\beta$-catenin signaling pathways influence LCSCs of HCC. HCC tumors and LCSC-containing HCC cell lines $\left(\mathrm{CD} 13^{+} \mathrm{CD} 133^{+}\right)$highly express LncTCF7, a critical regulator of LCSC self-renewal and tumor propagation. LncTCF7 recruits SWI/SNF complex binding to the TCF7 promoter and triggers TCF7 transcription and further activation of Wnt signaling-induced tumorigenic activity in liver cancer stem cells [188]. The long non-coding RNA, MEG3, a tumor suppressor in HCC, is reported to promote $\beta$-catenin degradation through increasing PTEN, leading to inhibition of hepatocarcinogenesis [189]. Lnc- $\beta$-Catm is promoted $\beta$-catenin stabilization by methylation of $\beta$-catenin by methyltransferase EZH2, thereby regulation of 
self-renewal of LCSCs [190]. LncDANCR in the stem-like cells of HCC is overexpression and further increases stemness features and promotes tumorigenesis of HCC via interacting with CTNNB1 mRNA and derepression of CTNNB1 [191]. Overexpression of LncDILC has dramatically decreased LCSCs expression by down-regulation of IL-6 transcription and abrogation of STAT3 activation then inhibition of IL-6/STAT3 signaling [192]. LncHDAC2 is highly expressed in $\mathrm{CD} 13^{+} \mathrm{CD} 133^{+}$cells, which promotes LCSC self-renewal and tumor progression by recruiting NuRD complex binding to the promoter of PTCH1, leading to inhibition of transcriptional activity and subsequent activation of Hh signaling [193]. The collective findings support the potential utility of ncRNAs as therapeutic targets against LCSCs in liver cancer.

\subsection{The LCSC Microenvironment}

Accumulating studies have shown that in addition to genetic, epigenetic, and signaling pathways, the microenvironment (niche) is an important influencer of stem cell behavior and differentiation. For instance, embryonic stem cells can significantly suppress tumorigenicity of aggressive cancer cells induced by the microenvironment [194]. Similarly, the tumor microenvironment influences cancer stem cell characteristics, leading to malignant phenotypes. For example, adding conditioned medium of mouse Lewis lung carcinoma to Nanog miPS cells leads to acquisition of CSC features and subsequent formation of spheroids in suspension culture, along with induction of high tumorigenicity and angiogenesis ability in Balb/c nude mice [195]. Single-cell CSC clones from human liver cancer microvascular endothelial cells were isolated and further treated with different tumor cell-derived conditioned culture media mimicking the tumor microenvironment. The results showed differentiation into the corresponding tumor cells and expression of specific tumor cell markers [196]. The major component of tumor stromal cells is cancer-associated fibroblasts (CAFs), which positively express CD90 and CD44. Upon co-culture with the human HCC cell lines Huh7 and JHH-6, CAFs enhanced mRNA expression of TGFB1 and FAP, compared to non-tumoral fibroblasts (NTF) (Figure 2G). These findings suggest that CAFs and HCC interact with each other to function in the maintenance and progression of liver disease [197]. The $\alpha$-SMA $(+)$ CAF population is regulated with T-ICs via activation of FRA1, dependent on ERK signaling activation by HGF. Activated FRA1 binds to downstream genes, stimulating HEY1 promoter transcription activity, and further enhances HCC self-renewal and tumorigenesis. These findings suggest that T-ICs of HCC are regulated extrinsically within the tumor microenvironment [198]. Isolation of the $\mathrm{CD} 44^{+}$population from human $\mathrm{HCC}$ cells and incubation with TAM induced expansion of this cell population and tumor sphere formation. In addition, TAMs and co-culture with HCC cell lines promoted expression of the cytokine IL- 6 and expansion of CD $44^{+}$cells. Knockdown of STAT3 or treatment with tocilizumab blocked IL-6 signaling and further inhibited TAM-stimulated activity of $\mathrm{CD} 44^{+}$cells (Figure 2G) [87]. In a hypoxic tumor microenvironment, rapid tumor growth further influences the proportion of LCSCs in HCC [199]. Artemis (ARTN), a hypoxia-responsive factor, is a necessary regulator promoting hypoxia-induced LCSC expansion of the $\mathrm{CD} 133^{+}$population in HCC, leading to enhanced tumor sphere formation and tumorigenesis [200]. Disulfiram (DS) is an anti-cancer drug that specifically inhibits the scavenger activity of reactive oxygen species (ROS) but has a very short half-life in the bloodstream. To solve this issue, a poly lactic-co-glycolic acid (PLGA)-encapsulated DS (DS-PLGA) was developed, which could inhibit the liver cancer stem cell population with a synergistic cell killing effect in combination with 5-FU or sorafenib. These findings suggest that the anti-HCC efficacy of DS is mediated through inhibition of LCSCs [201].

\section{Conclusions}

LCSCs can be identified based on a series of surface markers, including EpCAM, CD133, CD44, CD13, CD90, CD24, OV-6, CD47, and isolated SP cells. Functional studies suggest that LCSCs influence tumorigenesis, metastasis, and therapeutic resistance, as well as recurrence of HCC, and identification of this cell population should assist with diagnosis and prognosis predictions, patient 
stratification for administration of individualized therapy, and development of novel LCSC-targeted therapeutic strategies for HCC. LCSCs regulate tumor progression and therapeutic resistance via several mechanisms, including gene mutations, distribution of epigenetics, dysregulation of signaling, and alterations in the microenvironment. Small-molecule inhibitors against dysregulation of signaling pathways, such as Wnt/ $\beta$-catenin, Notch, Hh, and TGF- $\beta$, may effectively suppress LCSC-mediated tumorigenesis, metastasis, and self-renewal. OMP-18R5 and OMP-54F28 (inhibitors of the Wnt/ $\beta$-catenin signaling pathway), LED225 (a Hh inhibitor), and LY2157299 (a TGF- $\beta$ inhibitor) are progressing to clinical trials alone or in combination with other chemotherapeutic agents targeting LCSCs of HCC [133]. Oncolytic measles viruses specifically targeting CD133 (MV-141.7 and MV-AC133) and anti-surface marker antibodies have additionally been developed for clinical trials, including anti-EpCAM (VB4-845) and anti-CD44, which block surface markers of LCSCs alone or in conjunction with other chemotherapeutic agents for HCC. Epigenetic regulation plays a critical role in every step of tumorigenesis and progression. Some LCSC features are influenced by epigenetic control, and therefore, inhibitors of epigenetic regulation mechanisms (such as zebularine and SBHA) can achieve significant suppression of tumor-inducing characteristics of LCSCs. However, epigenetic modulation is not effective for targeting specific genes, which could become non-specific alterations. A number of other factors influence LCSCs, such as the tumor microenvironment and non-coding RNAs (miRNAs and lncRNAs). Currently, combinations of chemotherapy agents and small-molecule inhibitors are being developed to reduce LCSC populations for effective treatment of HCC. Since LCSCs share a number of similar characteristics with stem cells, distinguishing between the molecular signaling pathways or mechanisms of the two cell subpopulations remains a considerable challenge, and thus treatment approaches that target LCSCs are limited. Further research focus on the biological differences between normal stem cells and LCSCs is warranted. Elucidation of the unique biological or phenotypic properties of LCSCs should facilitate the development of effective therapeutic agents without the need for normal stem cells.

Author Contributions: The conceptualization, Y.-C.L. and K.-H.L.; investigation, Y.-C.L.; writing-original draft preparation, Y.-C.L.; writing-review and editing, Y.-C.L. and K.-H.L.; visualization, Y.-C.L.; supervision, K.-H.L.; funding acquisition, C.-T.Y. and K.-H.L. All authors have read and agreed to the published version of the manuscript.

Funding: This work was supported by grants from Chang Gung Memorial Hospital, Taoyuan, Taiwan (CMRPD1G0421, CMRPD1G0422, CMRPD1G0423, CMRPD1J0051, CMRPD1H0631, CMRPD1H0632, NMRPD1G0943, and NMRPD1G0953 to K. H. Lin) and from the Ministry of Science and Technology of the Republic of China (MOST 106-2320-B-182-031-MY3 and 106-2320-B-182-032-MY3 to K. H. Lin). We would like to thank the Taiwan Liver Cancer Network (TLCN) for providing the hepatoma tissue samples and related clinical data (all anonymous).

Conflicts of Interest: The authors declare no conflict of interest.

\section{References}

1. Yamashita, T.; Wang, X.W. Cancer stem cells in the development of liver cancer. J. Clin. Investig. 2013, 123, 1911-1918. [CrossRef] [PubMed]

2. Bugianesi, E. Review article: Steatosis, the metabolic syndrome and cancer. Aliment Pharmacol. Ther. 2005, 22 (Suppl. 2), 40-43. [CrossRef] [PubMed]

3. Villanueva, A.; Newell, P.; Chiang, D.Y.; Friedman, S.L.; Llovet, J.M. Genomics and signaling pathways in hepatocellular carcinoma. Semin. Liver Dis 2007, 27, 55-76. [CrossRef]

4. Feitelson, M.A.; Pan, J.; Lian, Z. Early molecular and genetic determinants of primary liver malignancy. Surg. Clin. North Am. 2004, 84, 339-354. [CrossRef]

5. Wang, X.W.; Hussain, S.P.; Huo, T.I.; Wu, C.G.; Forgues, M.; Hofseth, L.J.; Brechot, C.; Harris, C.C. Molecular pathogenesis of human hepatocellular carcinoma. Toxicology 2002, 181-182, 43-47. [CrossRef]

6. Thorgeirsson, S.S.; Grisham, J.W. Molecular pathogenesis of human hepatocellular carcinoma. Nat. Genet 2002, 31, 339-346. [CrossRef] 
7. Liu, Y.C.; Lu, L.F.; Li, C.J.; Sun, N.K.; Guo, J.Y.; Huang, Y.H.; Yeh, C.T.; Chao, C.C. Hepatitis B Virus X Protein Induces RHAMM-Dependent Motility in Hepatocellular Carcinoma Cells via PI3K-Akt-Oct-1 Signaling. Mol. Cancer Res. 2020, 18, 375-389. [CrossRef]

8. Whittaker, S.; Marais, R.; Zhu, A.X. The role of signaling pathways in the development and treatment of hepatocellular carcinoma. Oncogene 2010, 29, 4989-5005. [CrossRef]

9. Vu, N.B.; Nguyen, T.T.; Tran, L.C.; Do, C.D.; Nguyen, B.H.; Phan, N.K.; Pham, P.V. Doxorubicin and 5-fluorouracil resistant hepatic cancer cells demonstrate stem-like properties. Cytotechnology 2013, 65, 491-503. [CrossRef]

10. Lapidot, T.; Sirard, C.; Vormoor, J.; Murdoch, B.; Hoang, T.; Cacerescortes, J.; Minden, M.; Paterson, B.; Caligiuri, M.A.; Dick, J.E. A Cell Initiating Human Acute Myeloid-Leukemia after Transplantation into Scid Mice. Nature 1994, 367, 645-648. [CrossRef]

11. Nowell, P.C. The clonal evolution of tumor cell populations. Science 1976, 194, 23-28. [CrossRef] [PubMed]

12. Baylin, S.B.; Jones, P.A. A decade of exploring the cancer epigenome - biological and translational implications. Nat. Rev. Cancer 2011, 11, 726-734. [CrossRef] [PubMed]

13. Kim, C.F.B.; Jackson, E.L.; Woolfenden, A.E.; Lawrence, S.; Babar, I.; Vogel, S.; Crowley, D.; Bronson, R.T.; Jacks, T. Identification of bronchioalveolar stem cells in normal lung and lung cancer. Cell 2005, 121, 823-835. [CrossRef] [PubMed]

14. Hermann, P.C.; Huber, S.L.; Herrler, T.; Aicher, A.; Ellwart, J.W.; Guba, M.; Bruns, C.J.; Heeschen, C. Distinct populations of cancer stem cells determine tumor growth and metastatic activity in human pancreatic cancer. Cell Stem Cell 2007, 1, 313-323. [CrossRef] [PubMed]

15. Li, C.W.; Heidt, D.G.; Dalerba, P.; Burant, C.F.; Zhang, L.J.; Adsay, V.; Wicha, M.; Clarke, M.F.; Simeone, D.M. Identification of pancreatic cancer stem cells. Cancer Res. 2007, 67, 1030-1037. [CrossRef]

16. O'Brien, C.A.; Pollett, A.; Gallinger, S.; Dick, J.E. A human colon cancer cell capable of initiating tumour growth in immunodeficient mice. Nature 2007, 445, 106-110. [CrossRef]

17. Maugeri-Sacca, M.; Vigneri, P.; De Maria, R. Cancer stem cells and chemosensitivity. Clin. Cancer Res. 2011, 17, 4942-4947. [CrossRef]

18. Calcagno, A.M.; Salcido, C.D.; Gillet, J.P.; Wu, C.P.; Fostel, J.M.; Mumau, M.D.; Gottesman, M.M.; Varticovski, L.; Ambudkar, S.V. Prolonged drug selection of breast cancer cells and enrichment of cancer stem cell characteristics. J. Natl. Cancer Inst. 2010, 102, 1637-1652. [CrossRef]

19. Ji, J.; Wang, X.W. Clinical implications of cancer stem cell biology in hepatocellular carcinoma. Semin. Oncol. 2012, 39, 461-472. [CrossRef]

20. Guo, W.; Lasky, J.L., 3rd; Wu, H. Cancer stem cells. Pediatrics Res. 2006, 59, 59R-64R. [CrossRef]

21. Zhu, Z.; Hao, X.; Yan, M.; Yao, M.; Ge, C.; Gu, J.; Li, J. Cancer stem/progenitor cells are highly enriched in CD133+CD44+ population in hepatocellular carcinoma. Int. J. Cancer 2010, 126, 2067-2078. [CrossRef] [PubMed]

22. Ma, S.; Chan, K.W.; Lee, T.K.; Tang, K.H.; Wo, J.Y.; Zheng, B.J.; Guan, X.Y. Aldehyde dehydrogenase discriminates the CD133 liver cancer stem cell populations. Mol. Cancer Res. 2008, 6, 1146-1153. [CrossRef] [PubMed]

23. Hu, C.; Li, H.; Li, J.; Zhu, Z.; Yin, S.; Hao, X.; Yao, M.; Zheng, S.; Gu, J. Analysis of ABCG2 expression and side population identifies intrinsic drug efflux in the HCC cell line MHCC-97L and its modulation by Akt signaling. Carcinogenesis 2008, 29, 2289-2297. [CrossRef] [PubMed]

24. Haraguchi, N.; Utsunomiya, T.; Inoue, H.; Tanaka, F.; Mimori, K.; Barnard, G.F.; Mori, M. Characterization of a side population of cancer cells from human gastrointestinal system. Stem Cells 2006, 24, 506-513. [CrossRef]

25. Xin, H.W.; Ambe, C.M.; Hari, D.M.; Wiegand, G.W.; Miller, T.C.; Chen, J.Q.; Anderson, A.J.; Ray, S.; Mullinax, J.E.; Koizumi, T.; et al. Label-retaining liver cancer cells are relatively resistant to sorafenib. Gut 2013, 62, 1777-1786. [CrossRef]

26. Piao, L.S.; Hur, W.; Kim, T.K.; Hong, S.W.; Kim, S.W.; Choi, J.E.; Sung, P.S.; Song, M.J.; Lee, B.C.; Hwang, D.; et al. CD133+ liver cancer stem cells modulate radioresistance in human hepatocellular carcinoma. Cancer Lett. 2012, 315, 129-137. [CrossRef]

27. Ma, S.; Lee, T.K.; Zheng, B.J.; Chan, K.W.; Guan, X.Y. CD133+ HCC cancer stem cells confer chemoresistance by preferential expression of the Akt/PKB survival pathway. Oncogene 2008, 27, 1749-1758. [CrossRef] 
28. Fan, S.T.; Yang, Z.F.; Ho, D.W.; Ng, M.N.; Yu, W.C.; Wong, J. Prediction of posthepatectomy recurrence of hepatocellular carcinoma by circulating cancer stem cells: A prospective study. Ann. Surg. 2011, 254, 569-576. [CrossRef]

29. Philip, P.A.; Mooney, M.; Jaffe, D.; Eckhardt, G.; Moore, M.; Meropol, N.; Emens, L.; O’Reilly, E.; Korc, M.; Ellis, L.; et al. Consensus report of the national cancer institute clinical trials planning meeting on pancreas cancer treatment. J. Clin. Oncol. 2009, 27, 5660-5669. [CrossRef]

30. Yamashita, T.; Budhu, A.; Forgues, M.; Wang, X.W. Activation of hepatic stem cell marker EpCAM by Wnt-beta-catenin signaling in hepatocellular carcinoma. Cancer Res. 2007, 67, 10831-10839. [CrossRef]

31. Behari, J. The Wnt/beta-catenin signaling pathway in liver biology and disease. Expert. Rev. Gastroenterol. Hepatol. 2010, 4, 745-756. [CrossRef] [PubMed]

32. Cioffi, M.; Dorado, J.; Baeuerle, P.A.; Heeschen, C. EpCAM/CD3-Bispecific T-cell engaging antibody MT110 eliminates primary human pancreatic cancer stem cells. Clin. Cancer Res. 2012, 18, 465-474. [CrossRef] [PubMed]

33. Guan, D.X.; Shi, J.; Zhang, Y.; Zhao, J.S.; Long, L.Y.; Chen, T.W.; Zhang, E.B.; Feng, Y.Y.; Bao, W.D.; Deng, Y.Z.; et al. Sorafenib enriches epithelial cell adhesion molecule-positive tumor initiating cells and exacerbates a subtype of hepatocellular carcinoma through TSC2-AKT cascade. Hepatology 2015, 62, 1791-1803. [CrossRef] [PubMed]

34. Suetsugi, A.; Nagaki, M.; Aoki, H.; Motohashi, T.; Kunisada, T.; Moriwaki, H. Characterization of CD133(+) hepatocellular carcinoma cells as cancer stem/progenitor cells. Biochem. Bioph. Res. Commun. 2006, 351, 820-824. [CrossRef]

35. Ma, S.; Chan, K.W.; Hu, L.; Lee, T.K.; Wo, J.Y.; Ng, I.O.; Zheng, B.J.; Guan, X.Y. Identification and characterization of tumorigenic liver cancer stem/progenitor cells. Gastroenterology 2007, 132, 2542-2556. [CrossRef]

36. Rawal, P.; Siddiqui, H.; Hassan, M.; Choudhary, M.C.; Tripathi, D.M.; Nain, V.; Trehanpati, N.; Kaur, S. Endothelial Cell-Derived TGF-beta Promotes Epithelial-Mesenchymal Transition via CD133 in HBx-Infected Hepatoma Cells. Front. Oncol. 2019, 9, 308. [CrossRef]

37. Underhill, C. CD44: The hyaluronan receptor. J. Cell Sci. 1992, 103 Pt 2, 293-298.

38. Bourguignon, L.Y. CD44-mediated oncogenic signaling and cytoskeleton activation during mammary tumor progression. J. Mammary Gland Biol. Neoplasia 2001, 6, 287-297. [CrossRef]

39. Bourguignon, L.Y. Hyaluronan-mediated CD44 activation of RhoGTPase signaling and cytoskeleton function promotes tumor progression. Semin Cancer Biol. 2008, 18, 251-259. [CrossRef]

40. Bourguignon, L.Y.; Shiina, M.; Li, J.J. Hyaluronan-CD44 interaction promotes oncogenic signaling, microRNA functions, chemoresistance, and radiation resistance in cancer stem cells leading to tumor progression. Adv. Cancer Res. 2014, 123, 255-275. [CrossRef]

41. Gao, Y.; Ruan, B.; Liu, W.; Wang, J.; Yang, X.; Zhang, Z.; Li, X.; Duan, J.; Zhang, F.; Ding, R.; et al. Knockdown of CD44 inhibits the invasion and metastasis of hepatocellular carcinoma both in vitro and in vivo by reversing epithelial-mesenchymal transition. Oncotarget 2015, 6, 7828-7837. [CrossRef] [PubMed]

42. Park, N.R.; Cha, J.H.; Jang, J.W.; Bae, S.H.; Jang, B.; Kim, J.H.; Hur, W.; Choi, J.Y.; Yoon, S.K. Synergistic effects of CD44 and TGF-beta1 through AKT/GSK-3beta/beta-catenin signaling during epithelial-mesenchymal transition in liver cancer cells. Biochem. Biophys. Res. Commun. 2016, 477, 568-574. [CrossRef] [PubMed]

43. Haraguchi, N.; Ishii, H.; Mimori, K.; Tanaka, F.; Ohkuma, M.; Kim, H.M.; Akita, H.; Takiuchi, D.; Hatano, H.; Nagano, H.; et al. CD13 is a therapeutic target in human liver cancer stem cells. J. Clin. Investig. 2010, 120, 3326-3339. [CrossRef] [PubMed]

44. Sun, L.; Zhang, L.; Chen, J.; Li, C.; Sun, H.; Wang, J.; Xiao, H. Activation of Tyrosine Metabolism in CD13+ Cancer Stem Cells Drives Relapse in Hepatocellular Carcinoma. Cancer Res. Treat. 2019. [CrossRef]

45. Yang, Z.F.; Ho, D.W.; Ng, M.N.; Lau, C.K.; Yu, W.C.; Ngai, P.; Chu, P.W.; Lam, C.T.; Poon, R.T.; Fan, S.T. Significance of CD90+ cancer stem cells in human liver cancer. Cancer Cell 2008, 13, 153-166. [CrossRef]

46. Jia, Q.; Zhang, X.; Deng, T.; Gao, J. Positive correlation of Oct4 and ABCG2 to chemotherapeutic resistance in CD90(+)CD133(+) liver cancer stem cells. Cell Reprogram 2013, 15, 143-150. [CrossRef]

47. Sukowati, C.H.; Anfuso, B.; Torre, G.; Francalanci, P.; Croce, L.S.; Tiribelli, C. The expression of CD90/Thy-1 in hepatocellular carcinoma: An in vivo and in vitro study. PLoS ONE 2013, 8, e76830. [CrossRef] 
48. Xia, W.; Lo, C.M.; Poon, R.Y.C.; Cheung, T.T.; Chan, A.C.Y.; Chen, L.; Yang, S.; Tsao, G.S.W.; Wang, X.Q. Smad inhibitor induces CSC differentiation for effective chemosensitization in cyclin D1and TGF-beta/Smad-regulated liver cancer stem cell-like cells. Oncotarget 2017, 8, 38811-38824. [CrossRef]

49. Yang, X.R.; Xu, Y.; Yu, B.; Zhou, J.; Li, J.C.; Qiu, S.J.; Shi, Y.H.; Wang, X.Y.; Dai, Z.; Shi, G.M.; et al. CD24 Is a Novel Predictor for Poor Prognosis of Hepatocellular Carcinoma after Surgery. Clin. Cancer Res. 2009, 15, 5518-5527. [CrossRef]

50. Lee, T.K.W.; Castilho, A.; Cheung, V.C.H.; Tang, K.H.; Ma, S.; Irene, O.L.N. CD24(+) Liver Tumor-Initiating Cells Drive Self-Renewal and Tumor Initiation through STAT3-Mediated NANOG Regulation. Cell Stem Cell 2011, 9, 50-63. [CrossRef]

51. Lu, S.; Yao, Y.; Xu, G.L.; Zhou, C.; Zhang, Y.; Sun, J.; Jiang, R.Q.; Shao, Q.; Chen, Y. CD24 regulates sorafenib resistance via activating autophagy in hepatocellular carcinoma. Cell Death Dis. 2018, 9. [CrossRef] [PubMed]

52. Wang, R.H.; Li, Y.W.; Tsung, A.; Huang, H.; Du, Q.; Yang, M.Q.; Deng, M.H.; Xiong, S.; Wang, X.J.; Zhang, L.Y; et al. iNOS promotes CD24(+)CD133(+) liver cancer stem cell phenotype through a TACE/ADAM17-dependent Notch signaling pathway. Proc. Natl. Acad. Sci. USA 2018, 115, E10127-E10136. [CrossRef] [PubMed]

53. Yang, W.; Yan, H.X.; Chen, L.; Liu, Q.; He, Y.Q.; Yu, L.X.; Zhang, S.H.; Huang, D.D.; Tang, L.; Kong, X.N.; et al. Wnt/beta-catenin signaling contributes to activation of normal and tumorigenic liver progenitor cells. Cancer Res. 2008, 68, 4287-4295. [CrossRef] [PubMed]

54. Wang, C.; Wang, M.D.; Cheng, P.; Huang, H.; Dong, W.; Zhang, W.W.; Li, P.P.; Lin, C.; Pan, Z.Y.; Wu, M.C.; et al. Hepatitis B virus X protein promotes the stem-like properties of OV6(+) cancer cells in hepatocellular carcinoma. Cell Death Dis. 2017, 8, e2560. [CrossRef]

55. Shi, G.M.; Xu, Y.; Fan, J.; Zhou, J.; Yang, X.R.; Qiu, S.J.; Liao, Y.; Wu, W.Z.; Ji, Y.; Ke, A.W.; et al. Identification of side population cells in human hepatocellular carcinoma cell lines with stepwise metastatic potentials. J. Cancer Res. Clin. Oncol. 2008, 134, 1155-1163. [CrossRef]

56. Lo, J.; Lau, E.Y.; Ching, R.H.; Cheng, B.Y.; Ma, M.K.; Ng, I.O.; Lee, T.K. Nuclear factor kappa B-mediated CD47 up-regulation promotes sorafenib resistance and its blockade synergizes the effect of sorafenib in hepatocellular carcinoma in mice. Hepatology 2015, 62, 534-545. [CrossRef]

57. Roberts, D.D.; Kaur, S.; Soto-Pantoja, D.R. Therapeutic targeting of the thrombospondin-1 receptor CD47 to treat liver cancer. J. Cell. Commun. Signal 2015, 9, 101-102. [CrossRef]

58. Chen, J.; Zheng, D.X.; Yu, X.J.; Sun, H.W.; Xu, Y.T.; Zhang, Y.J.; Xu, J. Macrophages induce CD47 upregulation via IL-6 and correlate with poor survival in hepatocellular carcinoma patients. Oncoimmunology 2019, 8, e1652540. [CrossRef]

59. Oikawa, T.; Kamiya, A.; Zeniya, M.; Chikada, H.; Hyuck, A.D.; Yamazaki, Y.; Wauthier, E.; Tajiri, H.; Miller, L.D.; Wang, X.W.; et al. Sal-like protein 4 (SALL4), a stem cell biomarker in liver cancers. Hepatology 2013, 57, 1469-1483. [CrossRef]

60. Jiang, Y.L.; Li, W.; Shen, H.G.; Ren, R.; Xu, Z.H.; Wan, D.W.; Han, Y.; Kuang, Y.T.; Zhi, Q.M. SALL4 expression is associated with poor outcome in hepatocellular carcinoma. Int. J. Clin. Exp. Med. 2017, 10, 4267-4277.

61. Yamashita, T.; Honda, M.; Nakamoto, Y.; Baba, M.; Nio, K.; Hara, Y.; Zeng, S.S.; Hayashi, T.; Kondo, M.; Takatori, H.; et al. Discrete nature of EpCAM+ and CD90+ cancer stem cells in human hepatocellular carcinoma. Hepatology 2013, 57, 1484-1497. [CrossRef] [PubMed]

62. Zhu, L.; Zhang, W.; Wang, J.H.; Liu, R. Evidence of CD90+CXCR4+cells as circulating tumor stem cells in hepatocellular carcinoma. Tumor. Biol. 2015, 36, 5353-5360. [CrossRef] [PubMed]

63. Munz, M.; Baeuerle, P.A.; Gires, O. The emerging role of EpCAM in cancer and stem cell signaling. Cancer Res. 2009, 69, 5627-5629. [CrossRef] [PubMed]

64. Schmelzer, E.; Reid, L.M. EpCAM expression in normal, non-pathological tissues. Front Biosci. 2008, 13, 3096-3100. [CrossRef] [PubMed]

65. Baeuerle, P.A.; Gires, O. EpCAM (CD326) finding its role in cancer. Br. J. Cancer 2007, 96, 417-423. [CrossRef] [PubMed]

66. Trzpis, M.; McLaughlin, P.M.; de Leij, L.M.; Harmsen, M.C. Epithelial cell adhesion molecule: More than a carcinoma marker and adhesion molecule. Am. J. Pathol. 2007, 171, 386-395. [CrossRef]

67. Alibolandi, M.; Ramezani, M.; Sadeghi, F.; Abnous, K.; Hadizadeh, F. Epithelial cell adhesion molecule aptamer conjugated PEG-PLGA nanopolymersomes for targeted delivery of doxorubicin to human breast adenocarcinoma cell line in vitro. Int. J. Pharm. 2015, 479, 241-251. [CrossRef] 
68. Sun, Y.F.; Xu, Y.; Yang, X.R.; Guo, W.; Zhang, X.; Qiu, S.J.; Shi, R.Y.; Hu, B.; Zhou, J.; Fan, J. Circulating stem cell-like epithelial cell adhesion molecule-positive tumor cells indicate poor prognosis of hepatocellular carcinoma after curative resection. Hepatology 2013, 57, 1458-1468. [CrossRef]

69. Maetzel, D.; Denzel, S.; Mack, B.; Canis, M.; Went, P.; Benk, M.; Kieu, C.; Papior, P.; Baeuerle, P.A.; Munz, M.; et al. Nuclear signalling by tumour-associated antigen EpCAM. Nat. Cell Biol. 2009, 11, 162-171. [CrossRef]

70. Yamashita, T.; Ji, J.; Budhu, A.; Forgues, M.; Yang, W.; Wang, H.Y.; Jia, H.; Ye, Q.; Qin, L.X.; Wauthier, E.; et al. EpCAM-positive hepatocellular carcinoma cells are tumor-initiating cells with stem/progenitor cell features. Gastroenterology 2009, 136, 1012-1024. [CrossRef]

71. Lacoste, B.; Raymond, V.A.; Cassim, S.; Lapierre, P.; Bilodeau, M. Highly tumorigenic hepatocellular carcinoma cell line with cancer stem cell-like properties. PLoS ONE 2017, 12, e0171215. [CrossRef] [PubMed]

72. Nio, K.; Yamashita, T.; Okada, H.; Kondo, M.; Hayashi, T.; Hara, Y.; Nomura, Y.; Zeng, S.S.; Yoshida, M.; Hayashi, T.; et al. Defeating EpCAM(+) liver cancer stem cells by targeting chromatin remodeling enzyme CHD4 in human hepatocellular carcinoma. J. Hepatol. 2015, 63, 1164-1172. [CrossRef] [PubMed]

73. Ko, C.J.; Li, C.J.; Wu, M.Y.; Chu, P.Y. Overexpression of epithelial cell adhesion molecule as a predictor of poor outcome in patients with hepatocellular carcinoma. Exp. Ther. Med. 2018, 16, 4810-4816. [CrossRef] [PubMed]

74. Chen, Y.L.; Lin, P.Y.; Ming, Y.Z.; Huang, W.C.; Chen, R.F.; Chen, P.M.; Chu, P.Y. The effects of the location of cancer stem cell marker CD133 on the prognosis of hepatocellular carcinoma patients. BMC Cancer 2017, 17, 474. [CrossRef] [PubMed]

75. Glumac, P.M.; LeBeau, A.M. The role of CD133 in cancer: A concise review. Clin. Transl. Med. $2018,7$. [CrossRef] [PubMed]

76. Guler, G.; Guven, U.; Oktem, G. Characterization of CD133(+)/CD44(+) human prostate cancer stem cells with ATR-FTIR spectroscopy. Analyst 2019, 144, 2138-2149. [CrossRef]

77. Gzil, A.; Zarebska, I.; Bursiewicz, W.; Antosik, P.; Grzanka, D.; Szylberg, L. Markers of pancreatic cancer stem cells and their clinical and therapeutic implications. Mol. Biol. Rep. 2019, 46, 6629-6645. [CrossRef]

78. Peng, L.; Fu, J.; Wang, W.; Hofman, F.M.; Chen, T.C.; Chen, L. Distribution of cancer stem cells in two human brain gliomas. Oncol. Lett. 2019, 17, 2123-2130. [CrossRef]

79. Yin, S.; Li, J.; Hu, C.; Chen, X.; Yao, M.; Yan, M.; Jiang, G.; Ge, C.; Xie, H.; Wan, D.; et al. CD133 positive hepatocellular carcinoma cells possess high capacity for tumorigenicity. Int. J. Cancer 2007, 120, 1444-1450. [CrossRef]

80. Song, W.; Li, H.; Tao, K.; Li, R.; Song, Z.; Zhao, Q.; Zhang, F.; Dou, K. Expression and clinical significance of the stem cell marker CD133 in hepatocellular carcinoma. Int. J. Clin. Pract. 2008, 62, 1212-1218. [CrossRef]

81. Tsuchiya, A.; Kamimura, H.; Takamura, M.; Yamagiwa, S.; Matsuda, Y.; Sato, Y.; Nomoto, M.; Ichida, T.; Aoyagi, Y. Clinicopathological analysis of CD133 and NCAM human hepatic stem/progenitor cells in damaged livers and hepatocellular carcinomas. Hepatol. Res. 2009, 39, 1080-1090. [CrossRef] [PubMed]

82. Yoshikawa, S.; Zen, Y.; Fujii, T.; Sato, Y.; Ohta, T.; Aoyagi, Y.; Nakanuma, Y. Characterization of CD133+ parenchymal cells in the liver: Histology and culture. World J. Gastroenterol. 2009, 15, 4896-4906. [CrossRef] [PubMed]

83. Wang, Y.; Wu, G.; Fu, X.; Xu, S.; Wang, T.; Zhang, Q.; Yang, Y. Aquaporin 3 maintains the stemness of CD133+ hepatocellular carcinoma cells by activating STAT3. Cell Death Dis. 2019, 10, 465. [CrossRef] [PubMed]

84. Liu, K.; Hao, M.; Ouyang, Y.; Zheng, J.; Chen, D. CD133(+) cancer stem cells promoted by VEGF accelerate the recurrence of hepatocellular carcinoma. Sci. Rep. 2017, 7, 41499. [CrossRef]

85. Qiu, M.T.; Hu, J.W.; Yin, R.; Xu, L. Long noncoding RNA: An emerging paradigm of cancer research. Tumour. Biol. 2013, 34, 613-620. [CrossRef]

86. Ma, S.; Tang, K.H.; Chan, Y.P.; Lee, T.K.; Kwan, P.S.; Castilho, A.; Ng, I.; Man, K.; Wong, N.; To, K.F.; et al. miR-130b Promotes CD133(+) liver tumor-initiating cell growth and self-renewal via tumor protein 53-induced nuclear protein 1. Cell Stem Cell 2010, 7, 694-707. [CrossRef]

87. Wan, S.; Zhao, E.; Kryczek, I.; Vatan, L.; Sadovskaya, A.; Ludema, G.; Simeone, D.M.; Zou, W.; Welling, T.H. Tumor-associated macrophages produce interleukin 6 and signal via STAT3 to promote expansion of human hepatocellular carcinoma stem cells. Gastroenterology 2014, 147, 1393-1404. [CrossRef]

88. Asai, R.; Tsuchiya, H.; Amisaki, M.; Makimoto, K.; Takenaga, A.; Sakabe, T.; Hoi, S.; Koyama, S.; Shiota, G. CD44 standard isoform is involved in maintenance of cancer stem cells of a hepatocellular carcinoma cell line. Cancer Med. 2019, 8, 773-782. [CrossRef] 
89. Mima, K.; Okabe, H.; Ishimoto, T.; Hayashi, H.; Nakagawa, S.; Kuroki, H.; Watanabe, M.; Beppu, T.; Tamada, M.; Nagano, O.; et al. CD44s regulates the TGF-beta-mediated mesenchymal phenotype and is associated with poor prognosis in patients with hepatocellular carcinoma. Cancer Res. 2012, 72, 3414-3423. [CrossRef]

90. Mima, K.; Hayashi, H.; Imai, K.; Kuroki, H.; Nakagawa, S.; Okabe, H.; Chikamoto, A.; Watanabe, M.; Beppu, T.; Baba, H. High CD44s expression is associated with the EMT expression profile and intrahepatic dissemination of hepatocellular carcinoma after local ablation therapy. J. Hepatobiliary Pancreat. Sci. 2013, 20, 429-434. [CrossRef]

91. Dhar, D.; Antonucci, L.; Nakagawa, H.; Kim, J.Y.; Glitzner, E.; Caruso, S.; Shalapour, S.; Yang, L.; Valasek, M.A.; Lee, S.; et al. Liver Cancer Initiation Requires p53 Inhibition by CD44-Enhanced Growth Factor Signaling. Cancer Cell 2018, 33, 1061-1077.e1066. [CrossRef] [PubMed]

92. Tovuu, L.O.; Imura, S.; Utsunomiya, T.; Morine, Y.; Ikemoto, T.; Arakawa, Y.; Mori, H.; Hanaoka, J.; Kanamoto, M.; Sugimoto, K.; et al. Role of CD44 expression in non-tumor tissue on intrahepatic recurrence of hepatocellular carcinoma. Int. J. Clin. Oncol. 2013, 18, 651-656. [CrossRef] [PubMed]

93. Shipp, M.A.; Look, A.T. Hematopoietic Differentiation Antigens That Are Membrane-Associated Enzymes Cutting Is the Key. Blood 1993, 82, 1052-1070. [CrossRef] [PubMed]

94. Kim, H.M.; Haraguchi, N.; Ishii, H.; Ohkuma, M.; Okano, M.; Mimori, K.; Eguchi, H.; Yamamoto, H.; Nagano, H.; Sekimoto, M.; et al. Increased CD13 expression reduces reactive oxygen species, promoting survival of liver cancer stem cells via an epithelial-mesenchymal transition-like phenomenon. Ann. Surg Oncol. 2012, 19 (Suppl. 3), S539-S548. [CrossRef]

95. Yamanaka, C.; Wada, H.; Eguchi, H.; Hatano, H.; Gotoh, K.; Noda, T.; Yamada, D.; Asaoka, T.; Kawamoto, K.; Nagano, H.; et al. Clinical significance of CD13 and epithelial mesenchymal transition (EMT) markers in hepatocellular carcinoma. Jpn. J. Clin. Oncol. 2018, 48, 52-60. [CrossRef] [PubMed]

96. Barboni, E.; Gormley, A.M.; Rivero, F.B.P.; Vidal, M.; Morris, R.J. Activation of Lymphocytes-T by Cross-Linking of Glycophospholipid-Anchored Thy-1 Mobilizes Separate Pools of Intracellular 2nd Messengers to Those Induced by the Antigen Receptor Cd3 Complex. Immunology 1991, 72, 457-463. [PubMed]

97. Morris, R.J.; Tiveron, M.C.; Xue, G.P. The Relation of the Expression and Function of the Neuronal Glycoprotein Thy-I to Axonal Growth. Biochem. Soc. T 1992, 20, 401-405. [CrossRef]

98. Jeng, C.J.; McCarroll, S.A.; Martin, T.F.J.; Floor, E.; Adams, J.; Krantz, D.; Butz, S.; Edwards, R.; Schweitzer, E.S. Thy-1 is a component common to multiple populations of synaptic vesicles. J. Cell Biol. 1998, 140, 685-698. [CrossRef]

99. Leyton, L.; Schneider, P.; Labra, C.V.; Ruegg, C.; Hetz, C.A.; Quest, A.F.; Bron, C. Thy-1 binds to integrin beta(3) on astrocytes and triggers formation of focal contact sites. Curr. Biol. 2001, 11, 1028-1038. [CrossRef]

100. Yang, Z.F.; Ngai, P.; Ho, D.W.; Yu, W.C.; Ng, M.N.; Lau, C.K.; Li, M.L.; Tam, K.H.; Lam, C.T.; Poon, R.T.; et al. Identification of local and circulating cancer stem cells in human liver cancer. Hepatology 2008, 47, 919-928. [CrossRef]

101. Chiba, T.; Kanai, F.; Iwama, A.; Yokosuka, O. Circulating cancer stem cells: A novel prognostic predictor of hepatocellular carcinoma. Hepatobiliary Surg. Nutr. 2013, 2, 4-6. [CrossRef] [PubMed]

102. Guo, Z.; Li, L.Q.; Jiang, J.H.; Ou, C.; Zeng, L.X.; Xiang, B.D. Cancer stem cell markers correlate with early recurrence and survival in hepatocellular carcinoma. World J. Gastroenterol. 2014, 20, 2098-2106. [CrossRef] [PubMed]

103. Kim, B.H.; Park, J.W.; Kim, J.S.; Lee, S.K.; Hong, E.K. Stem Cell Markers Predict the Response to Sorafenib in Patients with Hepatocellular Carcinoma. Gut Liver 2019, 13, 342-348. [CrossRef] [PubMed]

104. Zhao, R.C.; Zhou, J.; Chen, K.F.; Gong, J.; Liu, J.; He, J.Y.; Guan, P.; Li, B.; Qin, Y. The prognostic value of combination of CD90 and OCT4 for hepatocellular carcinoma after curative resection. Neoplasma 2016, 63, 288-298. [CrossRef] [PubMed]

105. Gilliam, D.T.; Menon, V.; Bretz, N.P.; Pruszak, J. The CD24 surface antigen in neural development and disease. Neurobiol. Dis. 2017, 99, 133-144. [CrossRef] [PubMed]

106. Qiu, Q.; Hernandez, J.C.; Dean, A.M.; Rao, P.H.; Darlington, G.J. CD24-Positive Cells from Normal Adult Mouse Liver Are Hepatocyte Progenitor Cells. Stem Cells Dev. 2011, 20, 2177-2188. [CrossRef]

107. Dunsford, H.A.; Sell, S. Production of monoclonal antibodies to preneoplastic liver cell populations induced by chemical carcinogens in rats and to transplantable Morris hepatomas. Cancer Res. 1989, 49, 4887-4893. 
108. Strain, A.J.; Crosby, H.A.; Nijjar, S.; Kelly, D.A.; Hubscher, S.G. Human liver-derived stem cells. Semin. Liver Dis. 2003, 23, 373-384. [CrossRef]

109. Yang, W.; Wang, C.; Lin, Y.; Liu, Q.; Yu, L.X.; Tang, L.; Yan, H.X.; Fu, J.; Chen, Y.; Zhang, H.L.; et al. OV6(+) tumor-initiating cells contribute to tumor progression and invasion in human hepatocellular carcinoma. $J$. Hepatol. 2012, 57, 613-620. [CrossRef]

110. Goodell, M.A.; Brose, K.; Paradis, G.; Conner, A.S.; Mulligan, R.C. Isolation and functional properties of murine hematopoietic stem cells that are replicating in vivo. J. Exp. Med. 1996, 183, 1797-1806. [CrossRef]

111. Falciatori, I.; Borsellino, G.; Haliassos, N.; Boitani, C.; Corallini, S.; Battistini, L.; Bernardi, G.; Stefanini, M.; Vicini, E. Identification and enrichment of spermatogonial stem cells displaying side-population phenotype in immature mouse testis. Faseb. J. 2003, 17, 376-378. [CrossRef] [PubMed]

112. Chiba, T.; Kita, K.; Zheng, Y.W.; Yokosuka, O.; Saisho, H.; Iwama, A.; Nakauchi, H.; Taniguchi, H. Side population purified from hepatocellular carcinoma cells harbors cancer stem cell-like properties. Hepatology 2006, 44, 240-251. [CrossRef] [PubMed]

113. Zen, Y.; Fujii, T.; Yoshikawa, S.; Takamura, H.; Tani, T.; Ohta, T.; Nakanuma, Y. Histological and culture studies with respect to ABCG2 expression support the existence of a cancer cell hierarchy in human hepatocellular carcinoma. Am. J. Pathol. 2007, 170, 1750-1762. [CrossRef] [PubMed]

114. Willingham, S.B.; Volkmer, J.P.; Gentles, A.J.; Sahoo, D.; Dalerba, P.; Mitra, S.S.; Wang, J.; Contreras-Trujillo, H.; Martin, R.; Cohen, J.D.; et al. The CD47-signal regulatory protein alpha (SIRPa) interaction is a therapeutic target for human solid tumors. Proc. Natl. Acad. Sci. USA 2012, 109, 6662-6667. [CrossRef]

115. Lo, J.; Lau, E.Y.; So, F.T.; Lu, P.; Chan, V.S.; Cheung, V.C.; Ching, R.H.; Cheng, B.Y.; Ma, M.K.; Ng, I.O.; et al. Anti-CD47 antibody suppresses tumour growth and augments the effect of chemotherapy treatment in hepatocellular carcinoma. Liver Int. 2016, 36, 737-745. [CrossRef]

116. Mohammed, M.K.; Shao, C.; Wang, J.; Wei, Q.; Wang, X.; Collier, Z.; Tang, S.; Liu, H.; Zhang, F.; Huang, J.; et al. Wnt/beta-catenin signaling plays an ever-expanding role in stem cell self-renewal, tumorigenesis and cancer chemoresistance. Genes Dis. 2016, 3, 11-40. [CrossRef]

117. Kraus, C.; Liehr, T.; Hulsken, J.; Behrens, J.; Birchmeier, W.; Grzeschik, K.H.; Ballhausen, W.G. Localization of the human beta-catenin gene (CTNNB1) to 3p21: A region implicated in tumor development. Genomics 1994, 23, 272-274. [CrossRef]

118. Noordermeer, J.; Klingensmith, J.; Perrimon, N.; Nusse, R. dishevelled and armadillo act in the wingless signalling pathway in Drosophila. Nature 1994, 367, 80-83. [CrossRef]

119. Peifer, M.; Berg, S.; Reynolds, A.B. A repeating amino acid motif shared by proteins with diverse cellular roles. Cell 1994, 76, 789-791. [CrossRef]

120. MacDonald, B.T.; Tamai, K.; He, X. Wnt/beta-catenin signaling: Components, mechanisms, and diseases. Dev. Cell 2009, 17, 9-26. [CrossRef]

121. Morin, P.J. beta-catenin signaling and cancer. Bioessays 1999, 21, 1021-1030. [CrossRef]

122. Gedaly, R.; Galuppo, R.; Daily, M.F.; Shah, M.; Maynard, E.; Chen, C.; Zhang, X.; Esser, K.A.; Cohen, D.A.; Evers, B.M.; et al. Targeting the Wnt/beta-catenin signaling pathway in liver cancer stem cells and hepatocellular carcinoma cell lines with FH535. PLoS ONE 2014, 9, e99272. [CrossRef] [PubMed]

123. Behrens, J.; von Kries, J.P.; Kuhl, M.; Bruhn, L.; Wedlich, D.; Grosschedl, R.; Birchmeier, W. Functional interaction of beta-catenin with the transcription factor LEF-1. Nature 1996, 382, 638-642. [CrossRef] [PubMed]

124. Takigawa, Y.; Brown, A.M. Wnt signaling in liver cancer. Curr. Drug Targets 2008, 9, 1013-1024. [CrossRef]

125. Kim, J.Y.; Lee, H.Y.; Park, K.K.; Choi, Y.K.; Nam, J.S.; Hong, I.S. CWP232228 targets liver cancer stem cells through Wnt/beta-catenin signaling: A novel therapeutic approach for liver cancer treatment. Oncotarget 2016, 7, 20395-20409. [CrossRef]

126. Handeli, S.; Simon, J.A. A small-molecule inhibitor of Tcf/beta-catenin signaling down-regulates PPARgamma and PPARdelta activities. Mol. Cancer Ther. 2008, 7, 521-529. [CrossRef]

127. Tomizawa, M.; Shinozaki, F.; Motoyoshi, Y.; Sugiyama, T.; Yamamoto, S.; Ishige, N. FH535 suppresses the proliferation and motility of hepatocellular carcinoma cells. Int. J. Oncol. 2016, 48, 110-114. [CrossRef]

128. Turcios, L.; Vilchez, V.; Acosta, L.F.; Poyil, P.; Butterfield, D.A.; Mitov, M.; Marti, F.; Gedaly, R. Sorafenib and FH535 in combination act synergistically on hepatocellular carcinoma by targeting cell bioenergetics and mitochondrial function. Dig. Liver Dis. 2017, 49, 697-704. [CrossRef] 
129. Galuppo, R.; Maynard, E.; Shah, M.; Daily, M.F.; Chen, C.; Spear, B.T.; Gedaly, R. Synergistic inhibition of HCC and liver cancer stem cell proliferation by targeting RAS/RAF/MAPK and WNT/beta-catenin pathways. Anticancer Res. 2014, 34, 1709-1713.

130. Ni, C.X.; Qi, Y.; Zhang, J.; Liu, Y.; Xu, W.H.; Xu, J.; Hu, H.G.; Wu, Q.Y.; Wang, Y.; Zhang, J.P. WM130 preferentially inhibits hepatic cancer stem-like cells by suppressing AKT/GSK3beta/beta-catenin signaling pathway. Oncotarget 2016, 7, 79544-79556. [CrossRef]

131. Qian, L.; Liu, Y.; Xu, Y.; Ji, W.; Wu, Q.; Liu, Y.; Gao, Q.; Su, C. Matrine derivative WM130 inhibits hepatocellular carcinoma by suppressing EGFR/ERK/MMP-2 and PTEN/AKT signaling pathways. Cancer Lett. 2015, 368, 126-134. [CrossRef] [PubMed]

132. Liu, Y.; Qi, Y.; Bai, Z.H.; Ni, C.X.; Ren, Q.H.; Xu, W.H.; Xu, J.; Hu, H.G.; Qiu, L.; Li, J.Z.; et al. A novel matrine derivate inhibits differentiated human hepatoma cells and hepatic cancer stem-like cells by suppressing PI3K/AKT signaling pathways. Acta Pharmacol. Sin. 2017, 38, 120-132. [CrossRef] [PubMed]

133. Chan, K.K.; Lo, R.C. Deregulation of Frizzled Receptors in Hepatocellular Carcinoma. Int. J. Mol. Sci. 2018, 19, 313. [CrossRef] [PubMed]

134. Le, P.N.; McDermott, J.D.; Jimeno, A. Targeting the Wnt pathway in human cancers: Therapeutic targeting with a focus on OMP-54F28. Pharmacol. Ther. 2015, 146, 1-11. [CrossRef] [PubMed]

135. Artavanis-Tsakonas, S.; Rand, M.D.; Lake, R.J. Notch signaling: Cell fate control and signal integration in development. Science 1999, 284, 770-776. [CrossRef] [PubMed]

136. Kumar, R.; Juillerat-Jeanneret, L.; Golshayan, D. Notch Antagonists: Potential Modulators of Cancer and Inflammatory Diseases. J. Med. Chem. 2016, 59, 7719-7737. [CrossRef] [PubMed]

137. Kopan, R. Notch signaling. Cold Spring Harb. Perspect. Biol. 2012, 4. [CrossRef]

138. Luo, J.; Wang, P.; Wang, R.H.; Wang, J.L.; Liu, M.; Xiong, S.; Li, Y.W.; Cheng, B. The Notch pathway promotes the cancer stem cell characteristics of CD90(+) cells in hepatocellular carcinoma. Oncotarget 2016, 7, 9526-9538. [CrossRef]

139. Zhu, P.; Wang, Y.; Du, Y.; He, L.; Huang, G.; Zhang, G.; Yan, X.; Fan, Z. C8orf4 negatively regulates self-renewal of liver cancer stem cells via suppression of NOTCH2 signalling. Nat. Commun. 2015, 6, 7122. [CrossRef]

140. Zhang, Q.Y.; Lu, C.J.; Fang, T.; Wang, Y.C.; Hu, W.H.; Qiao, J.; Liu, B.; Liu, J.; Chen, N.P.; Li, M.Y.; et al. Notch3 functions as a regulator of cell self-renewal by interacting with the beta-catenin pathway in hepatocellular carcinoma. Oncotarget 2015, 6, 3669-3679. [CrossRef]

141. Wang, R.; Sun, Q.; Wang, P.; Liu, M.; Xiong, S.; Luo, J.; Huang, H.; Du, Q.; Geller, D.A.; Cheng, B. Notch and $\mathrm{Wnt} /$ beta-catenin signaling pathway play important roles in activating liver cancer stem cells. Oncotarget 2016, 7, 5754-5768. [CrossRef] [PubMed]

142. Wu, C.X.; Xu, A.; Zhang, C.C.; Olson, P.; Chen, L.; Lee, T.K.; Cheung, T.T.; Lo, C.M.; Wang, X.Q. Notch Inhibitor PF-03084014 Inhibits Hepatocellular Carcinoma Growth and Metastasis via Suppression of Cancer Stemness due to Reduced Activation of Notch1-Stat3. Mol. Cancer Ther. 2017, 16, 1531-1543. [CrossRef] [PubMed]

143. Ihrie, R.A.; Shah, J.K.; Harwell, C.C.; Levine, J.H.; Guinto, C.D.; Lezameta, M.; Kriegstein, A.R.; Alvarez-Buylla, A. Persistent sonic hedgehog signaling in adult brain determines neural stem cell positional identity. Neuron 2011, 71, 250-262. [CrossRef] [PubMed]

144. Buller, N.V.; Rosekrans, S.L.; Westerlund, J.; van den Brink, G.R. Hedgehog signaling and maintenance of homeostasis in the intestinal epithelium. Physiol. (Bethesda) 2012, 27, 148-155. [CrossRef] [PubMed]

145. Solanas, G.; Benitah, S.A. Regenerating the skin: A task for the heterogeneous stem cell pool and surrounding niche. Nat. Rev. Mol. Cell Biol. 2013, 14, 737-748. [CrossRef] [PubMed]

146. Petrova, R.; Joyner, A.L. Roles for Hedgehog signaling in adult organ homeostasis and repair. Development 2014, 141, 3445-3457. [CrossRef] [PubMed]

147. Hanna, A.; Shevde, L.A. Hedgehog signaling: Modulation of cancer properies and tumor mircroenvironment. Mol. Cancer 2016, 15, 24. [CrossRef]

148. Arzumanyan, A.; Sambandam, V.; Clayton, M.M.; Choi, S.S.; Xie, G.; Diehl, A.M.; Yu, D.Y.; Feitelson, M.A. Hedgehog signaling blockade delays hepatocarcinogenesis induced by hepatitis B virus $\mathrm{X}$ protein. Cancer Res. 2012, 72, 5912-5920. [CrossRef] 
149. Zhang, D.; Cao, L.; Li, Y.; Lu, H.; Yang, X.; Xue, P. Expression of glioma-associated oncogene 2 (Gli 2) is correlated with poor prognosis in patients with hepatocellular carcinoma undergoing hepatectomy. World J. Surg. Oncol. 2013, 11, 25. [CrossRef]

150. Chun, H.W.; Hong, R. Significance of the hedgehog pathway-associated proteins Gli-1 and Gli-2 and the epithelial-mesenchymal transition-associated proteins Twist and E-cadherin in hepatocellular carcinoma. Oncol. Lett. 2016, 12, 1753-1762. [CrossRef]

151. Wang, F.; Ma, L.; Zhang, Z.; Liu, X.; Gao, H.; Zhuang, Y.; Yang, P.; Kornmann, M.; Tian, X.; Yang, Y. Hedgehog Signaling Regulates Epithelial-Mesenchymal Transition in Pancreatic Cancer Stem-Like Cells. J. Cancer 2016, 7, 408-417. [CrossRef] [PubMed]

152. Rimkus, T.K.; Carpenter, R.L.; Qasem, S.; Chan, M.; Lo, H.W. Targeting the Sonic Hedgehog Signaling Pathway: Review of Smoothened and GLI Inhibitors. Cancers (Basel) 2016, 8, 22. [CrossRef] [PubMed]

153. Incardona, J.P.; Gaffield, W.; Kapur, R.P.; Roelink, H. The teratogenic Veratrum alkaloid cyclopamine inhibits sonic hedgehog signal transduction. Development 1998, 125, 3553-3562. [PubMed]

154. Sicklick, J.K.; Li, Y.X.; Jayaraman, A.; Kannangai, R.; Qi, Y.; Vivekanandan, P.; Ludlow, J.W.; Owzar, K.; Chen, W.; Torbenson, M.S.; et al. Dysregulation of the Hedgehog pathway in human hepatocarcinogenesis. Carcinogenesis 2006, 27, 748-757. [CrossRef]

155. Hirotsu, M.; Setoguchi, T.; Sasaki, H.; Matsunoshita, Y.; Gao, H.; Nagao, H.; Kunigou, O.; Komiya, S. Smoothened as a new therapeutic target for human osteosarcoma. Mol. Cancer 2010, 9. [CrossRef]

156. Mimeault, M.; Johansson, S.L.; Henichart, J.P.; Depreux, P.; Batra, S.K. Cytotoxic Effects Induced by Docetaxel, Gefitinib, and Cyclopamine on Side Population and Nonside Population Cell Fractions from Human Invasive Prostate Cancer Cells. Mol. Cancer Ther. 2010, 9, 617-630. [CrossRef]

157. Robarge, K.D.; Brunton, S.A.; Castanedo, G.M.; Cui, Y.; Dina, M.S.; Goldsmith, R.; Gould, S.E.; Guichert, O.; Gunzner, J.L.; Halladay, J.; et al. GDC-0449-a potent inhibitor of the hedgehog pathway. Bioorg Med. Chem. Lett. 2009, 19, 5576-5581. [CrossRef]

158. Philips, G.M.; Chan, I.S.; Swiderska, M.; Schroder, V.T.; Guy, C.; Karaca, G.F.; Moylan, C.; Venkatraman, T.; Feuerlein, S.; Syn, W.K.; et al. Hedgehog Signaling Antagonist Promotes Regression of Both Liver Fibrosis and Hepatocellular Carcinoma in a Murine Model of Primary Liver Cancer. PLoS ONE 2011, 6. [CrossRef]

159. Kwon, H.; Song, K.; Han, C.; Chen, W.; Wang, Y.; Dash, S.; Lim, K.; Wu, T. Inhibition of hedgehog signaling ameliorates hepatic inflammation in mice with nonalcoholic fatty liver disease. Hepatology 2016, 63, 1155-1169. [CrossRef]

160. Fu, J.; Rodova, M.; Roy, S.K.; Sharma, J.; Singh, K.P.; Srivastava, R.K.; Shankar, S. GANT-61 inhibits pancreatic cancer stem cell growth in vitro and in NOD/SCID/IL2R gamma null mice xenograft. Cancer Lett. 2013, 330, 22-32. [CrossRef]

161. Wang, Y.; Han, C.; Lu, L.; Magliato, S.; Wu, T. Hedgehog signaling pathway regulates autophagy in human hepatocellular carcinoma cells. Hepatology 2013, 58, 995-1010. [CrossRef] [PubMed]

162. Xu, P.; Liu, J.; Derynck, R. Post-translational regulation of TGF-beta receptor and Smad signaling. FEBS Lett. 2012, 586, 1871-1884. [CrossRef] [PubMed]

163. Meindl-Beinker, N.M.; Matsuzaki, K.; Dooley, S. TGF-beta signaling in onset and progression of hepatocellular carcinoma. Dig. Dis. 2012, 30, 514-523. [CrossRef] [PubMed]

164. Sakaki-Yumoto, M.; Katsuno, Y.; Derynck, R. TGF-beta family signaling in stem cells. Biochim. Biophys. Acta 2013, 1830, 2280-2296. [CrossRef] [PubMed]

165. Fan, Q.M.; Jing, Y.Y.; Yu, G.F.; Kou, X.R.; Ye, F.; Gao, L.; Li, R.; Zhao, Q.D.; Yang, Y.; Lu, Z.H.; et al. Tumor-associated macrophages promote cancer stem cell-like properties via transforming growth factor-beta1-induced epithelial-mesenchymal transition in hepatocellular carcinoma. Cancer Lett. 2014, 352, 160-168. [CrossRef] [PubMed]

166. You, H.; Ding, W.; Rountree, C.B. Epigenetic regulation of cancer stem cell marker CD133 by transforming growth factor-beta. Hepatology 2010, 51, 1635-1644. [CrossRef] [PubMed]

167. Serova, M.; Tijeras-Raballand, A.; Dos Santos, C.; Albuquerque, M.; Paradis, V.; Neuzillet, C.; Benhadji, K.A.; Raymond, E.; Faivre, S.; de Gramont, A. Effects of TGF-beta signalling inhibition with galunisertib (LY2157299) in hepatocellular carcinoma models and in ex vivo whole tumor tissue samples from patients. Oncotarget 2015, 6, 21614-21627. [CrossRef] 
168. Yang, Y.; Liu, Q.; Li, Z.; Zhang, R.; Jia, C.; Yang, Z.; Zhao, H.; Ya, S.; Mao, R.; Ailijiang, T.; et al. GP73 promotes epithelial-mesenchymal transition and invasion partly by activating TGF-beta1/Smad2 signaling in hepatocellular carcinoma. Carcinogenesis 2018, 39, 900-910. [CrossRef]

169. Bach, P.; Abel, T.; Hoffmann, C.; Gal, Z.; Braun, G.; Voelker, I.; Ball, C.R.; Johnston, I.C.; Lauer, U.M.; Herold-Mende, C.; et al. Specific elimination of CD133+ tumor cells with targeted oncolytic measles virus. Cancer Res. 2013, 73, 865-874. [CrossRef]

170. Ogawa, K.; Tanaka, S.; Matsumura, S.; Murakata, A.; Ban, D.; Ochiai, T.; Irie, T.; Kudo, A.; Nakamura, N.; Tanabe, M.; et al. EpCAM-targeted therapy for human hepatocellular carcinoma. Ann. Surg. Oncol. 2014, 21, 1314-1322. [CrossRef]

171. Biggers, K.; Scheinfeld, N. VB4-845, a conjugated recombinant antibody and immunotoxin for head and neck cancer and bladder cancer. Curr. Opin. Mol. 2008, 10, 176-186.

172. Wang, L.; Su, W.; Liu, Z.; Zhou, M.; Chen, S.; Chen, Y.; Lu, D.; Liu, Y.; Fan, Y.; Zheng, Y.; et al. CD44 antibody-targeted liposomal nanoparticles for molecular imaging and therapy of hepatocellular carcinoma. Biomaterials 2012, 33, 5107-5114. [CrossRef] [PubMed]

173. Guo, Q.; Sui, Z.G.; Xu, W.; Quan, X.H.; Sun, J.L.; Li, X.; Ji, H.Y.; Jing, F.B. Ubenimex suppresses Pim-3 kinase expression by targeting CD13 to reverse MDR in HCC cells. Oncotarget 2017, 8, 72652-72665. [CrossRef] [PubMed]

174. Dawson, M.A.; Kouzarides, T. Cancer epigenetics: From mechanism to therapy. Cell 2012, 150, $12-27$. [CrossRef]

175. Rosner, M.; Hengstschlager, M. Targeting epigenetic readers in cancer. N. Engl. J. Med. 2012, 367, $1764-1765$. [CrossRef]

176. Waldmann, T.; Schneider, R. Targeting histone modifications-epigenetics in cancer. Curr. Opin. Cell Biol. 2013, 25, 184-189. [CrossRef]

177. Zhang, H.; Tian, X.J.; Mukhopadhyay, A.; Kim, K.S.; Xing, J. Statistical mechanics model for the dynamics of collective epigenetic histone modification. Phys. Rev. Lett. 2014, 112, 068101. [CrossRef]

178. Marquardt, J.U.; Factor, V.M.; Thorgeirsson, S.S. Epigenetic regulation of cancer stem cells in liver cancer: Current concepts and clinical implications. J. Hepatol. 2010, 53, 568-577. [CrossRef]

179. Raggi, C.; Factor, V.M.; Seo, D.; Holczbauer, A.; Gillen, M.C.; Marquardt, J.U.; Andersen, J.B.; Durkin, M.; Thorgeirsson, S.S. Epigenetic reprogramming modulates malignant properties of human liver cancer. Hepatology 2014, 59, 2251-2262. [CrossRef]

180. Zeng, S.S.; Yamashita, T.; Kondo, M.; Nio, K.; Hayashi, T.; Hara, Y.; Nomura, Y.; Yoshida, M.; Hayashi, T.; Oishi, N.; et al. The transcription factor SALL4 regulates stemness of EpCAM-positive hepatocellular carcinoma. J. Hepatol. 2014, 60, 127-134. [CrossRef]

181. Zhang, J.; Luo, N.; Luo, Y.; Peng, Z.P.; Zhang, T.; Li, S.L. microRNA-150 inhibits human CD133-positive liver cancer stem cells through negative regulation of the transcription factor c-Myb. Int. J. Oncol. 2012, 40, 747-756. [CrossRef] [PubMed]

182. Zhang, Q.Z.; Yang, Z.; Shan, J.J.; Liu, L.M.; Liu, C.G.; Shen, J.J.; Chen, X.J.; Xu, Y.M.; Chen, J.; Ma, Q.H.; et al. MicroRNA-449a maintains self-renewal in liver cancer stem-like cells by targeting Tcf3. Oncotarget 2017, 8 , 110187-110200. [CrossRef] [PubMed]

183. Chai, S.; Ng, K.Y.; Tong, M.; Lau, E.Y.; Lee, T.K.; Chan, K.W.; Yuan, Y.F.; Cheung, T.T.; Cheung, S.T.; Wang, X.Q.; et al. Octamer 4/microRNA-1246 signaling axis drives Wnt/beta-catenin activation in liver cancer stem cells. Hepatology 2016, 64, 2062-2076. [CrossRef] [PubMed]

184. Zhou, J.N.; Zeng, Q.; Wang, H.Y.; Zhang, B.; Li, S.T.; Nan, X.; Cao, N.; Fu, C.J.; Yan, X.L.; Jia, Y.L.; et al. MicroRNA-125b attenuates epithelial-mesenchymal transitions and targets stem-like liver cancer cells through small mothers against decapentaplegic 2 and 4. Hepatology 2015, 62, 801-815. [CrossRef]

185. Xia, H.P.; Ooi, L.L.P.J.; Hui, K.M. MicroRNA-216a/217-induced epithelial-mesenchymal transition targets PTEN and SMAD7 to promote drug resistance and recurrence of liver cancer. Hepatology 2013, 58, 629-641. [CrossRef]

186. Lin, Y.H.; Wu, M.H.; Huang, Y.H.; Yeh, C.T.; Chi, H.C.; Tsai, C.Y.; Chuang, W.Y.; Yu, C.J.; Chung, I.H.; Chen, C.Y.; et al. Thyroid hormone negatively regulates tumorigenesis through suppression of BC200. Endocr.-Relat. Cancer 2018, 25, 967-979. [CrossRef]

187. Chen, Z.Z.; Huang, L.; Wu, Y.H.; Zhai, W.J.; Zhu, P.P.; Gao, Y.F. LncSox4 promotes the self-renewal of liver tumour-initiating cells through Stat3-mediated Sox4 expression. Nat. Commun. 2016, 7. [CrossRef] 
188. Wang, Y.; He, L.; Du, Y.; Zhu, P.; Huang, G.; Luo, J.; Yan, X.; Ye, B.; Li, C.; Xia, P.; et al. The long noncoding RNA lncTCF7 promotes self-renewal of human liver cancer stem cells through activation of Wnt signaling. Cell Stem Cell 2015, 16, 413-425. [CrossRef]

189. Zheng, Q.D.; Lin, Z.J.; Xu, J.; Lu, Y.N.; Meng, Q.Y.; Wang, C.; Yang, Y.X.; Xin, X.R.; Li, X.N.; Pu, H.; et al. Long noncoding RNA MEG3 suppresses liver cancer cells growth through inhibiting beta-catenin by activating PKM2 and inactivating PTEN. Cell Death Dis. 2018, 9. [CrossRef]

190. Zhu, P.; Wang, Y.; Huang, G.; Ye, B.; Liu, B.; Wu, J.; Du, Y.; He, L.; Fan, Z. Inc-beta-Catm elicits EZH2-dependent beta-catenin stabilization and sustains liver CSC self-renewal. Nat. Struct. Mol. Biol. 2016, 23, 631-639. [CrossRef]

191. Yuan, S.X.; Wang, J.; Yang, F.; Tao, Q.F.; Zhang, J.; Wang, L.L.; Yang, Y.; Liu, H.; Wang, Z.G.; Xu, Q.G.; et al. Long noncoding RNA DANCR increases stemness features of hepatocellular carcinoma by derepression of CTNNB1. Hepatology 2016, 63, 499-511. [CrossRef] [PubMed]

192. Wang, X.; Sun, W.; Shen, W.; Xia, M.; Chen, C.; Xiang, D.; Ning, B.; Cui, X.; Li, H.; Li, X.; et al. Long non-coding RNA DILC regulates liver cancer stem cells via IL-6/STAT3 axis. J. Hepatol. 2016, 64, 1283-1294. [CrossRef] [PubMed]

193. Wu, J.; Zhu, P.; Lu, T.; Du, Y.; Wang, Y.; He, L.; Ye, B.; Liu, B.; Yang, L.; Wang, J.; et al. The long non-coding RNA LncHDAC2 drives the self-renewal of liver cancer stem cells via activation of Hedgehog signaling. J. Hepatol. 2019, 70, 918-929. [CrossRef]

194. Postovit, L.M.; Margaryan, N.V.; Seftor, E.A.; Kirschmann, D.A.; Lipavsky, A.; Wheaton, W.W.; Abbott, D.E.; Seftor, R.E.; Hendrix, M.J. Human embryonic stem cell microenvironment suppresses the tumorigenic phenotype of aggressive cancer cells. Proc. Natl. Acad. Sci. USA 2008, 105, 4329-4334. [CrossRef] [PubMed]

195. Chen, L.; Kasai, T.; Li, Y.; Sugii, Y.; Jin, G.; Okada, M.; Vaidyanath, A.; Mizutani, A.; Satoh, A.; Kudoh, T.; et al. A model of cancer stem cells derived from mouse induced pluripotent stem cells. PLoS ONE 2012, 7, e33544. [CrossRef] [PubMed]

196. Liu, H.; Zhang, W.; Jia, Y.; Yu, Q.; Grau, G.E.; Peng, L.; Ran, Y.; Yang, Z.; Deng, H.; Lou, J. Single-cell clones of liver cancer stem cells have the potential of differentiating into different types of tumor cells. Cell Death Dis. 2013, 4, e857. [CrossRef] [PubMed]

197. Sukowati, C.H.; Anfuso, B.; Croce, L.S.; Tiribelli, C. The role of multipotent cancer associated fibroblasts in hepatocarcinogenesis. BMC Cancer 2015, 15, 188. [CrossRef]

198. Lau, E.Y.; Lo, J.; Cheng, B.Y.; Ma, M.K.; Lee, J.M.; Ng, J.K.; Chai, S.; Lin, C.H.; Tsang, S.Y.; Ma, S.; et al. Cancer-Associated Fibroblasts Regulate Tumor-Initiating Cell Plasticity in Hepatocellular Carcinoma through c-Met/FRA1/HEY1 Signaling. Cell Rep. 2016, 15, 1175-1189. [CrossRef]

199. Muramatsu, S.; Tanaka, S.; Mogushi, K.; Adikrisna, R.; Aihara, A.; Ban, D.; Ochiai, T.; Irie, T.; Kudo, A.; Nakamura, N.; et al. Visualization of stem cell features in human hepatocellular carcinoma reveals in vivo significance of tumor-host interaction and clinical course. Hepatology 2013, 58, 218-228. [CrossRef]

200. Zhang, M.; Zhang, W.; Wu, Z.; Liu, S.; Sun, L.; Zhong, Y.; Zhang, X.; Kong, X.; Qian, P.; Zhang, H.; et al. Artemin is hypoxia responsive and promotes oncogenicity and increased tumor initiating capacity in hepatocellular carcinoma. Oncotarget 2016, 7, 3267-3282. [CrossRef]

201. Wang, Z.; Tan, J.; McConville, C.; Kannappan, V.; Tawari, P.E.; Brown, J.; Ding, J.; Armesilla, A.L.; Irache, J.M.; Mei, Q.B.; et al. Poly lactic-co-glycolic acid controlled delivery of disulfiram to target liver cancer stem-like cells. Nanomedicine 2017, 13, 641-657. [CrossRef] [PubMed]

(C) 2020 by the authors. Licensee MDPI, Basel, Switzerland. This article is an open access article distributed under the terms and conditions of the Creative Commons Attribution (CC BY) license (http://creativecommons.org/licenses/by/4.0/). 